\title{
Recording the Common Good: Record-keeping practices in New Zealand not-for-profit organisations
}

\section{by}

\section{Reesha Ranchod}

Submitted to the School of Information Management, Victoria University of Wellington in partial fulfilment of the requirements for the degree of Master of Library and Information Studies

\section{May 2021}




\section{Abstract:}

Research Problem: There are no studies about records management in New Zealand notfor-profit organisations. However, records management research has established issues in archival theory. The current practice of not-for-profit organisations are unknown. The purpose of this research project is to confirm relevance of the records lifecycle and the records continuum. In addition, to establish whether the record-keeping issued by Archives New Zealand meet requirements of not-for-profit organisations. This research built on current research in records management, to identify an overview of record-keeping processes. The research contributes to the records management body of knowledge.

Methodology: Using purposive sampling and Qualtrics survey software, five hundered and eighty organisations were given an anonomyous survey link. Twitter, Facebook and Linkedin posts were utilised to engage New Zealand not-for-profit organisations. Fourty respondents involved with governance, management or admininistration completed an online survey, along with twenty incomplete responses, and three respondents that did not fulfil the screening criteria.

Results: This research project confirmed the application of the record continuum, as $82.5 \%$ of respondents digitise records. $40 \%$ of respondents do not have complete faith in their records policy. In addition, 56.4\% want a record-keeping schedule developed for not-for-profit organisations.

Implications: As this research confirms and builds on records management research, no comparative research internationally addresses records management for not-for-profit organisations. This research should be developed further, applying mixed methods and observing multiple organisations to confirm needs before Archives New Zealand create targeted standards for not-for-profit organisations. In addition, the professional bodies of ARANZ and RIMPA should consider delivering education to not-for-profit organiastions, concreting engagement with community archives in the future.

Keywords: records management, record keeping, not-for-profit, charities community organisations, archives New Zealand 


\section{Acknowledgements:}

To the souls that are in my life, you all influence me positively or negatively. Every day, I get smarter, stronger and better.

For my loved ones:

- Ancestors: Nana Dhedia, Ranchhod Nana, Mani Ranchhod, Dayal Soma Patel, and Saraswati Soma Patel. Even though you are not on this earth, thank you for always watching over me and giving me your blessings.

- Family: Babu Nana Ranchod, Daksha Ranchod, and Nalini Natasha Ranchod. Even though we are countries and COVID-19 bubble apart, thank you for all your patience and love. Nalini Masi, Thank you for all the food deliveries every week.

For my friends:

Anne Barwell, Ailsa Leibrick, Fiona Erasmuson, Kirstie Stevens, Kylie Millard, Michael Barton, Heather Cryan, Suzanne Markwitz, Katrina Sudfelt, Penelope Masters, Chelsie Offord, Hayley Vonder, Jay Shulamith, Cheryl Wigmore, Madeline Deroles, Lydia Stewart, Emily and Lance Andresen. Thank you for being patient with me for all the times I delay decisions, double-booked events, and not show up to meetings.

To Hutt City Libraries:

- Sandra Mann. Thank you for recognising my outstanding Mahi for the patrons of Hutt City, and telling me a master's degree was worth it. Kat Cuttriss. Thank you for recognising my higher study, years of being a Library Assistant experience, to fulfil several secondments that pushed how I view Library Science.

- War Memorial Mentors: Sam Voss, Nicole Noldus, Joanne Basford, Jen Hutchinson, Michael Doherty, Carol Fifield. I learned through trial by fire, and you all gave me a lot of responsibility earlier in my career.

- Petone Community: Liz Castle, Trisha Meehan Jenny Richards, Tamadea Jasul, Salote Cama, and Clark Stiles. Thank you for the year in Petone Community Library and for teaching me the importance of Family and Local History Library Services.

- Naenae Community: Fiona Barkess, I will never slow down! Thank you for booking all my study leave before you left. Kristine Saunders, thank you for believing in me and giving me the courage to continue. Terisa Amosa, Mele Tonga, Matt Dickie, Beth Trethewey, Natalie Gajdusek and Paul Sanders. Thanks for asking me how my time off was (even though it was always studying) and listening to me repeat myself. 


\section{Table of Contents}

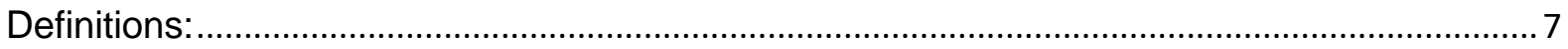

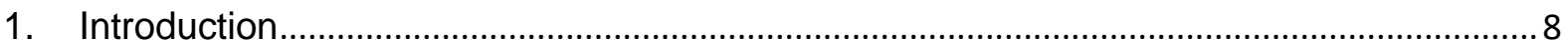

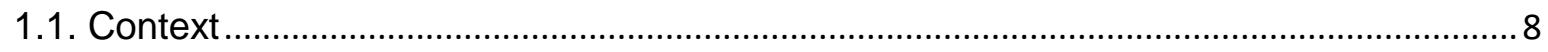

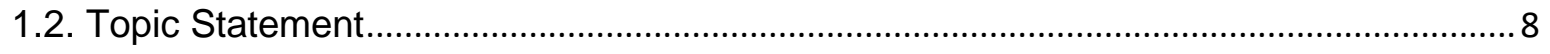

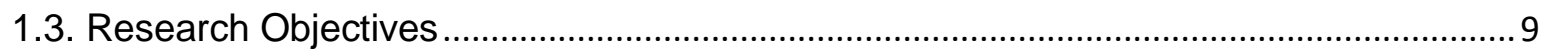

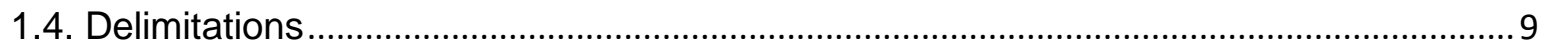

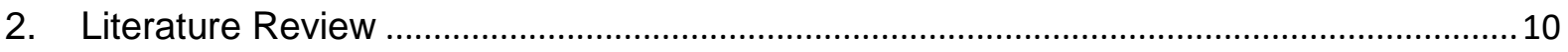

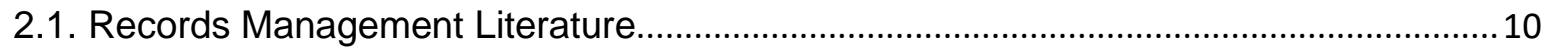

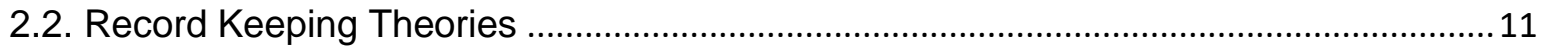

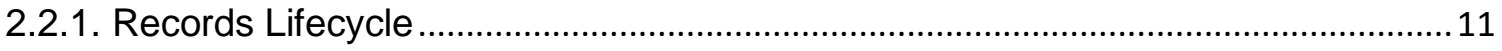

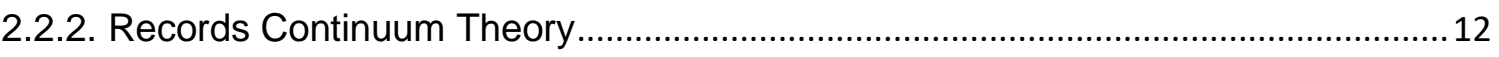

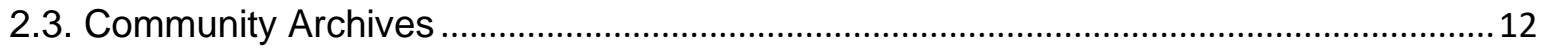

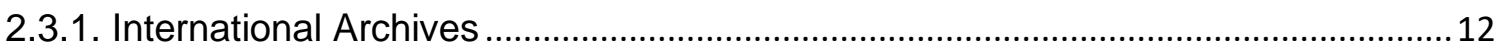

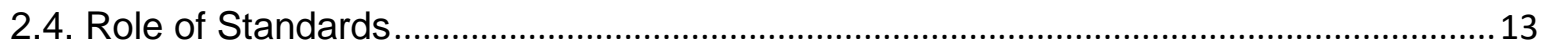

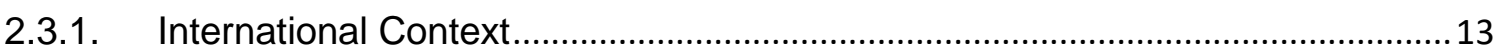

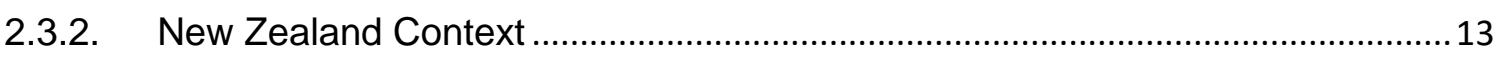

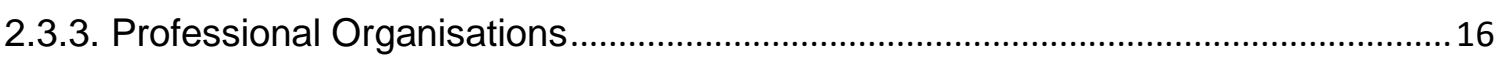

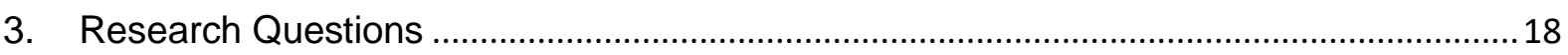

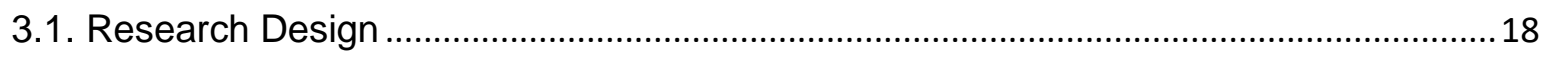

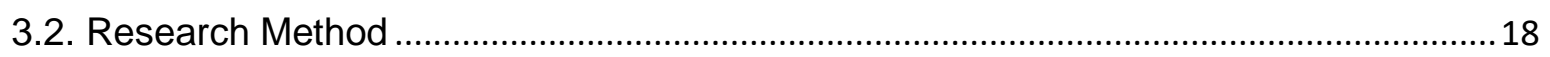

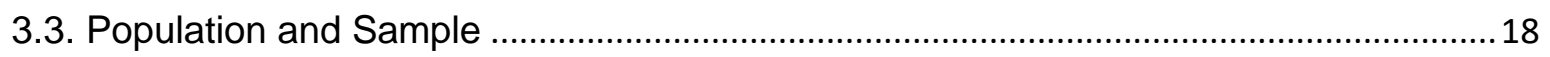

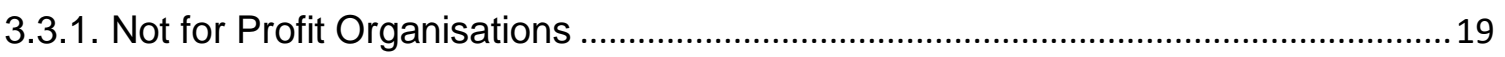

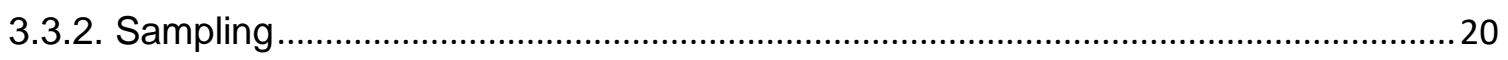

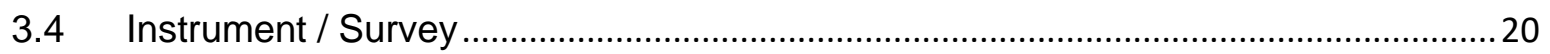

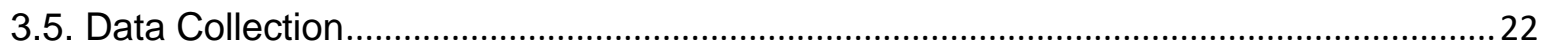

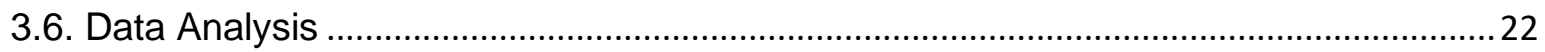

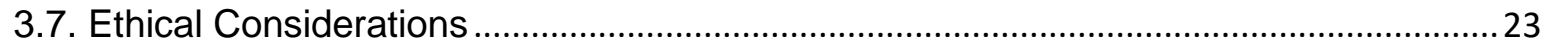

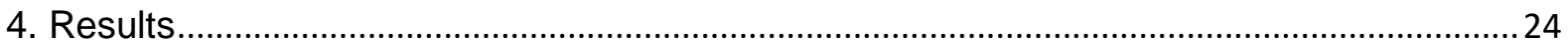

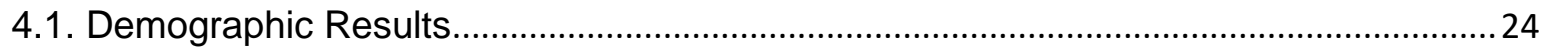

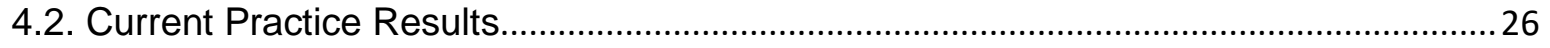

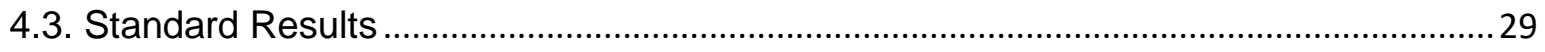

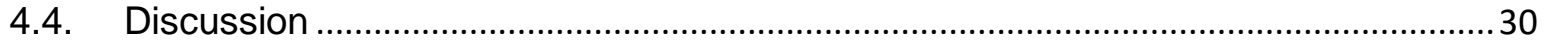

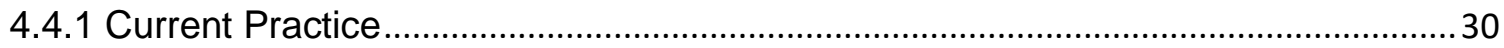

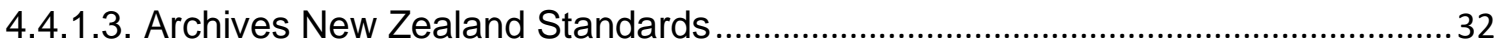

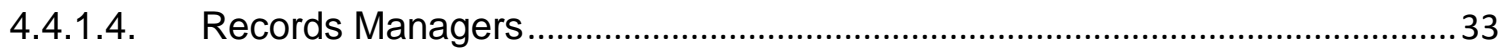




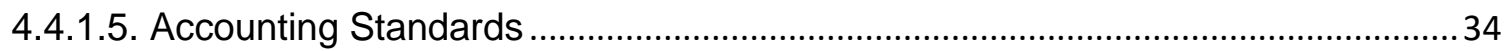

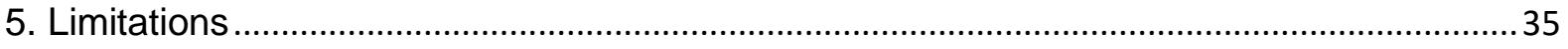

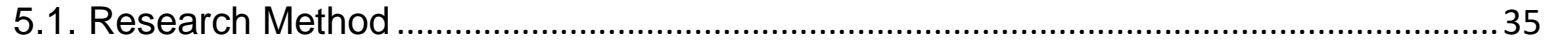

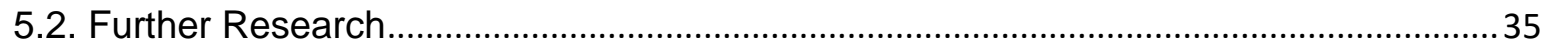

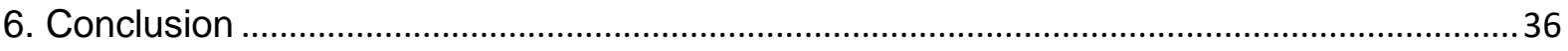

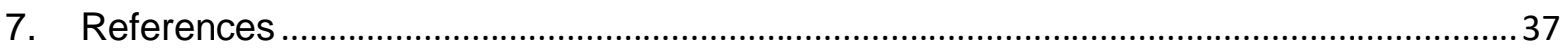

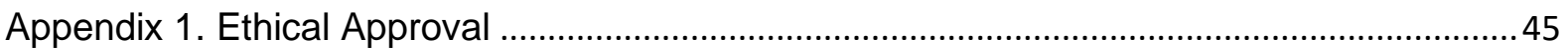

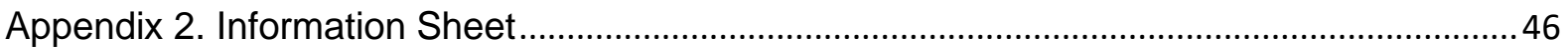

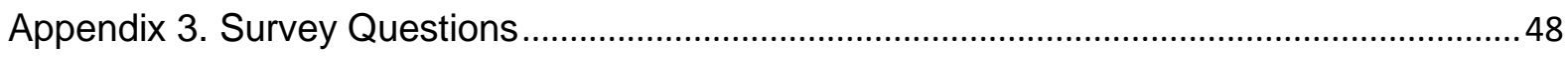

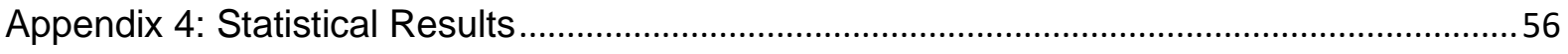




\section{List of Figures:}

Figure 1: Manage information

Figure 2: Summary of Accounting Tiers (Charities Services, 2021) .....................................................................15

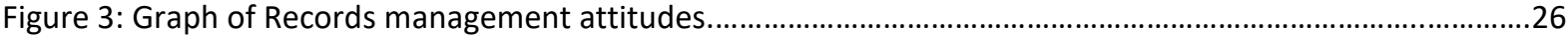

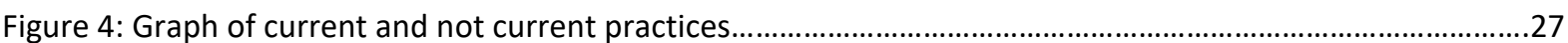

\section{List of Tables:}

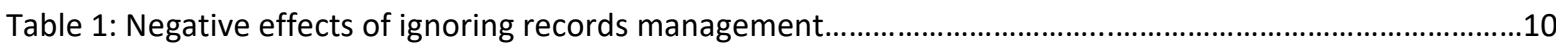

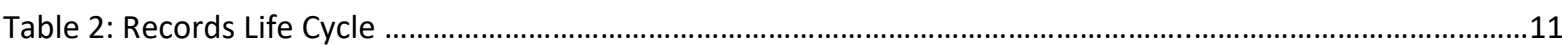

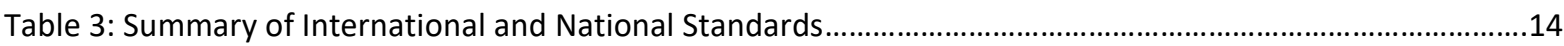

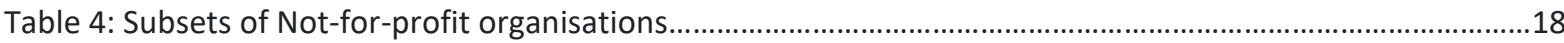

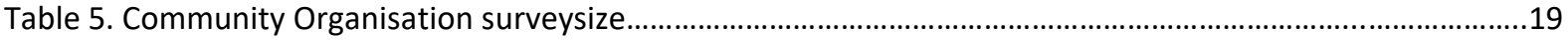

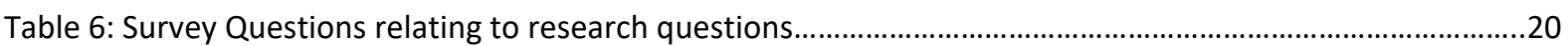

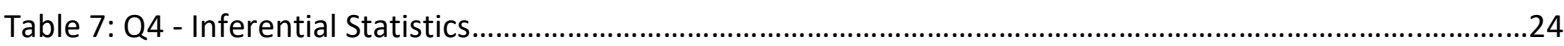

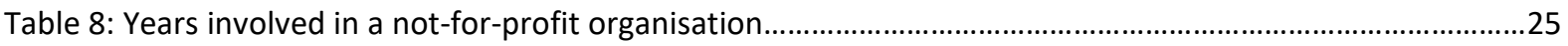

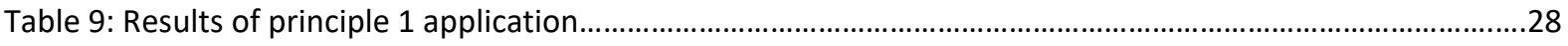

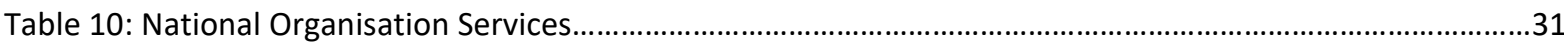

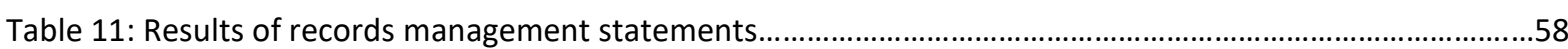

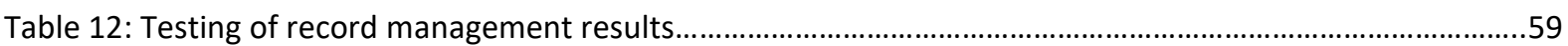

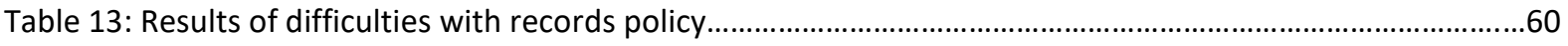

Table 14: Results of Current and Not Current Practice statements........................................................................61

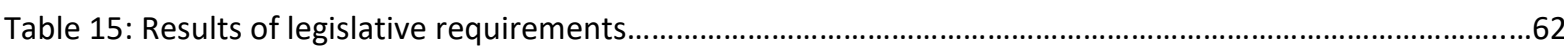

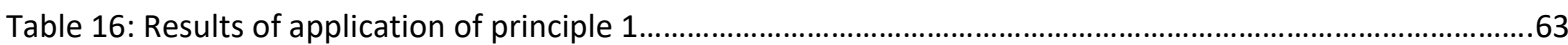

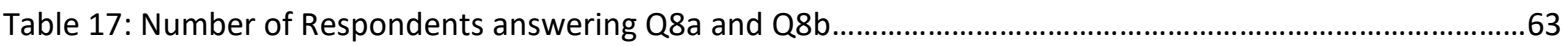

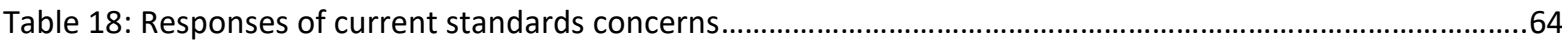

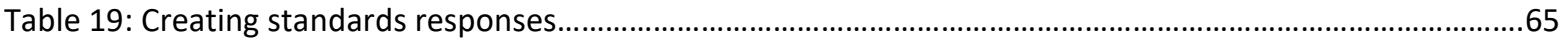

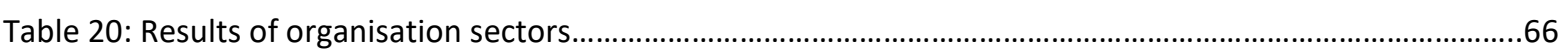

Table 21: Comparison of non-profit institutions from Statistics New Zealand (2018).......................................66

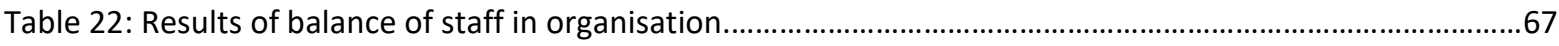

Table 23: Comparison from Statistics New Zealand (2018); makeup of employees and volunteers...................68

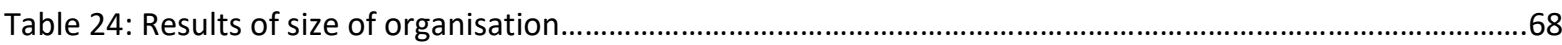

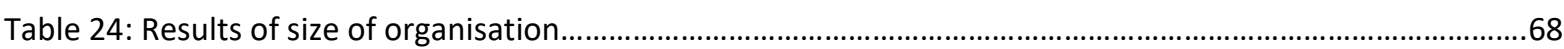

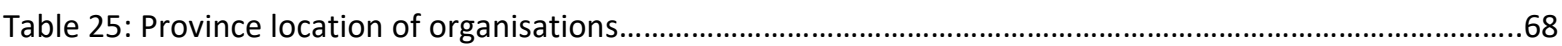

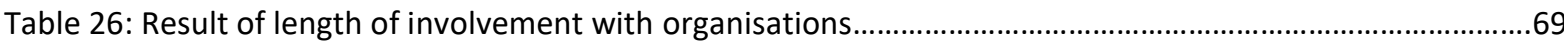




\section{Definitions:}

Records: information created, received and maintained as evidence and as an asset by an organization or person, in pursuit of legal obligations or in the transaction of business (International Standards Organisation, 2012).

Records management: Field of management responsible for the efficient and systematic control of the creation, receipt, maintenance, use and disposition of records, including processes for capturing and maintaining evidence of and information about business activities and transactions in the form of records (International Standards Organisation, 2012).

Record-keeping: the activity of organising and storing all the documents, files, invoices, etc. relating to a company's or organisation's activities. (Cambridge Dictionary. 2020)

Archives: a collection of historical documents or records providing information about a place, institution, or group of people. (International Council of Archives, 2020)

Charities: A registered charity, that operates in accordance with the Charities Act 2005 (Department of Internal Affairs [DIA], (2020).

Incorporated Societies: A group or association that chooses to register under the Incorporated Societies Act 1908, for the purpose to operate for an extended period of time. The group has its own legal identity, separate to its members (New Zealand Companies Office, 2019).

Trusts: a trust is a legally binding arrangement between a settlor, trustee, and beneficiaries. The person who establishes the trust is called the settlor. the trustee is a person who manages the assets, 'for the beneficiaries (Perpetual Guardian, 2019).

Clubs: An association of people for some common goal, usually jointly supported and meets periodically (Clubs New Zealand, 2020).

Not-for-profit organisations: A group comprised of charities, incorporated societies, trusts and sports clubs. They are also called community organisations that work toward the public good. 


\section{Introduction}

"Two roads diverged in a wood, and I-

I took the one less travelled by,

And that has made all the difference" (Frost \& Untermeyer, 1991).

Records management has been thought of as a process to create and store information (Oliver \& Foscarini, 2020). The conversation of records management is continuously evolving with archives and records managers. Record-keeping is an essential part of information management for the New Zealand government and businesses. However, there is an evident lack of records management research for not-for-profit organisations within New Zealand.

\subsection{Context}

Many not-for-profit organisations support an estimated New Zealand population of 5,024,000 (Britannica, 2021). In 2018, there were 115,770 not-for-profit organisations, compared with 114,110 in 2013 (Statistics New Zealand, 2018). As they grow and evolve in importance to the communities in New Zealand (O'Brien et al., 2009), this valuable sector faces significant funding issues while managing short term risks, technology, and people (Grant Thornton New Zealand Ltd, 2016). Current research about not-for-profit organisations is mainly concerned about management and marketing (Edney, 2009; Hill, 2016; Crawford, 2018), with lack of records management knowledge from volunteers. Record-keeping has been thought of as a process to create and store information being an underlying theme.

\subsection{Topic Statement}

Not-for-profit organisations provide several benefits to the average citizen in New Zealand, yet there is a lack of research analysing how these organisations apply records management theory. In addition, there is not enough information or assistance from government agencies to meet their record-keeping needs. Leading organisations such as Archives New Zealand, ARANZ (Archives and Records Association of New Zealand) and RIMPA (Records and Information Management Professionals Australasia) should provide more assistance and learning opportunities for not-for-profit organisations. When there is engagement and continuing support from professional organisations, it creates compulsion and transparency and a mutually beneficial relationship. Without the discipline of records management, the professional body of knowledge will not be fully utilised for New Zealand communities and cannot be used to its full potential. 


\subsection{Research Objectives}

The objectives of this study are to explore current records management practices and awareness of records management principles defined in records management standards.

\subsection{Delimitations}

- The focus of this research was not-for-profit organisations such as a charity, trust or incorporated society.

- The focus emphasised a New Zealand context. Thus, New Zealand standards were under review.

- This study does not investigate the direction of ARANZ or RIMPA and does not take into consideration the staffing and budget of Archives New Zealand. 


\section{Literature Review}

\subsection{Records Management Literature}

Records management is a body of thought separated into three branches comprising of information retrieval, records lifecycle, and information policy (Buckland, 1994 p. 348). Archives New Zealand (2014) further explained records management as an integrated framework of policies, processes, systems, and tools to enable organisations to create and maintain trustworthy evidence of business activities. This research investigates what is known about records management and applies them to not-for-profit organisations.

As records management is a crucial part of organisations, this research focuses on record keeping. Benton (2008) summarised records as having three elements: content, context, and structure. The importance of records has been proven over government organisations (Shepard, Stevenson \& Flinn 2010; Ndenje-Sichalwe, Ngulube, \& Stilwell, 2011; Chorley, 2017) and business entities (Wong, 2007). Table 1 lists the external and internal dangers of not following proper records management. Thus record-keeping is essential for all not-for-profit organisations.

\begin{tabular}{|c|c|}
\hline $\begin{array}{l}\text { External legislative requirements } \\
\text { (Not-for-Profit NZ, 2013): }\end{array}$ & $\begin{array}{c}\text { Internal negative effects } \\
\text { (Explora - Australia/New Zealand 2013): }\end{array}$ \\
\hline $\begin{array}{l}\text { - Prosecutable by government } \\
\text { agencies: } \\
\circ \text { Income Tax Act } 2007 \\
\circ \quad \text { Privacy Act } 2020 \\
\circ \quad \text { Copyright Act } 1994 \\
\circ \quad \text { Health and Safety at Work } \\
\quad \text { Act } 2015 \\
\text { - Removal of protected status } \\
\text { (Sports New Zealand, } 2021 \text { b): } \\
\circ \quad \text { Incorporated Society Act } \\
\quad 1908 \\
\circ \quad \text { Charities Act } 2005 \\
\circ \quad \text { Trusts Act } 2019\end{array}$ & $\begin{array}{l}\text { Danger of harming the integrity of the } \\
\text { organisation. } \\
\text { - Volunteers or managers of the community } \\
\text { organisation could be held liable. } \\
\text { - Poor decision-making because of } \\
\text { information not being available. } \\
\text { - Wasting resources, time, or money to locate } \\
\text { documents. } \\
\text { - Keeping records that should otherwise be } \\
\text { destroyed. } \\
\text { Duplicated records taking up extra floor } \\
\text { space. }\end{array}$ \\
\hline
\end{tabular}

Table 1: Negative effects of ignoring records management.

Knowledge management is the process of creating knowledge such as communication, human resources, intellectual capital, and brands information (Quintas, Lefere \& Jones, 1997). The dimensions in this body of thinking include leadership, efficiency and business strategy (Jennex \& Smolnik, 2011), which differ from the physical documentation 
of records management. Records management can be thought of as a one part of knowledge management, and this distinction is necessary for organisations.

\subsection{Record Keeping Theories}

Records professionals use proven theories such as the records life cycle to manage information. Current theories that will be applied in this research are the records life cycle model, and the records continuum theory.

\subsubsection{Records Lifecycle}

The first theory is the records life cycle, shown in Table 2. The concept began in the United States of America in the 1930s (Hare and McLeod, 1997; Penn, Pennix and Coulson, 1994 as cited in Yusof \& Chell, 2000). This model takes the records through a process of creation, organisation, storage, and disposition by the people involved (Erlandsson, 1997, as cited in Yus of \& Chell, 2000). Regardless of whether the model holds three, five, or six stages, there is an ongoing linear process from beginning to end (Xiaomi, 2001). Organisations can apply this theory, to create record keeping policies.

\section{The first stage: Create}

-When a record is created internally (United Nations, 2021).

- Usually relates to a decision or record made internally.

- Often classified as the receipt of records (Shepherd \& Yeo, 2013).

The second stage: Organisation / Usage

-The classification of a record (United Nations, 2021).

- For paper-based record-keeping, the organisation is the physical location of a record.

-This theory holds that all records move through the records lifecycle and the use of the record diminishes (United Nations, 2021).

\section{The third stage: Preservation / Storage}

- How the record is kept in the long term. Most people would put their physical records in a box, or electronic records in a folder, never to be seen again.

-An organisation chooses what context their documents hold. Metadata is then applied, to assist in identification and organisation.

\section{The fourth stage: Archive / Disposal}

-A records retention schedule to inform a timeline for destruction archival.

- Existing retention schedules (Ministry of Education, n.d.) for schools do not relevant to not-forprofit organisations.

-To protect and properly organise the organisation's records (United Nations, 2021) regardless of age.

Table 2: Records Life Cycle. 


\subsubsection{Limitations of the Model}

There are several limitations of this theory, making it not suitable for all organisations. Sletten (1999) surmised the theory is static, as records go through the cycle in an assembly line. The traditional life cycle model is more concerned with paper records. Differently, digital records are placed within a schema and hold attributing metadata to it, allowing multiple uses and locations to store record within a relational database (Yusof \& Chell, 2000). The records life cycle does not recognise this reality, forcing record keepers to manage records strictly (Parker, 2000). This model does not hold true relevance for organisations today.

\subsubsection{Records Continuum Theory}

Upward (2000) created the records continuum theory as an improvement to the record lifecycle theory. The main benefit is that a record is "in a process of becoming" (McKemmish, 2001). For community organisations, it means there are no boundaries in which a record begins and ends. Sletten (1999) concludes that the records continuum theory holds more freedom than the records lifecycle theory. The records continuum theory holds more support within Australia (Ketelaar, 2005; Williams, 2006; Andersen, 2007; Brunskill \& Demb, 2012; and Piggot, 2012) due to the rejection of fixed records. Organisations can use the records continuum more reliably to apply record-keeping standards.

\subsection{Community Archives}

Another body of thinking relating to records management is community archives. A record created in the fourth stage of the life cycle theory can enter an archive. The focus is on keeping the record as an object to reflect on in the future. Community archives are alternative options to fulfil a gap where a national body would otherwise look away (Caswell, Cifor \& Raminez, 2016).

\subsubsection{International Archives}

Several countries use community archives successfully. The United Kingdom lead with the Community Archives and Heritage Group (CAHG) as a community-based archive (Gilliland and Flynn, 2014). This relational database allows community groups to locate verified donated material. In addition, it allows collaboration with other agencies to encourage further refining of standards (Young, 2017). This level of collaboration is not available in New Zealand.

The United States and Australian literature additionally recognises the importance of people in community archives. As archivists engage with the community, they find no set record-keeping standard to depend upon (Shepard, Stevenson \& Flinn, 2010; Copeland, 
Lipinski, \& Jones, 2017). In contrast, National Archives Australia [NAA] (2021a) created standards from ISO for government agencies. There is better support for Australian community archives, with online programs, grants and outreach programs available (National Archives Australia, 2021b). New Zealand could follow from international approaches to community archives.

There is a current focus on Archives New Zealand to improve the knowledge base, leading to created research. A recent ARANZ (2021) study evaluated The Community Archive register located on the Archives New Zealand (2020b) website. The previous Community Archive was regularly used initially. Several issues formed, including lack of engagement from institutions and researchers. The report (ARANZ) recommended increased funding and ongoing support so the archive can thrive in the future. Even with imperfections (Schwartz and Cook, 2002; Flinn, Stevens \& Shepard, 2009; Edney, 2009), issues in community archives find similarities to issues in records management.

\subsection{Role of Standards}

The theories mentioned earlier influence record-keeping standards internationally and domestically, but the standards themselves are not suitable for not-for-profit organisations.

\subsubsection{International Context}

The International Organisation for Standardisation (ISO) certification ensures that record-keeping upholds quality standards and provides assurance (Mead Metals, 2020). The standard relating to record-keeping is ISO: 15489-1:2016 (Shepard \& Yeo, 2013; Oliver and Foscarini, 2020). Multiple countries worldwide adopt these standards to develop standards that then create records policy for individual organisations. In the United Kingdom, the United States, Canada, and Australia, there are no record-keeping standards (Table 3) to assist notfor-profit organisations. New Zealand follows the same theme, with standards created to assist government bodies. As the literature narrows in scope, it shows how not-for-profit organisations worldwide do not have record-keeping guidelines.

\subsubsection{New Zealand Context}

\subsubsection{CommunityNet Aotearoa}

CommunityNet Aotearoa is a website that focuses on providing the right tools for notfor-profit organisations run by the NZ Navigator Trust. Research by O'Brien, Sanders and Tennant (2009) identified that not-for-profit organisations have issues compiling government requirements. Assistance is provided through how-to guides, stories \& case studies, 
information \& advice, and tools \& templates (NZ Navigator Trust, 2021b). The pages themselves cover the organisation of physical and digital records and keep records private (NZ Navigator Trust, 2021a). The failure holds as official information change; information on this page fails to update.

Accepted contributions have been accepted from New Zealand individuals and organisations (NZ Navigator Trust, 2021c), reinforcing that a not-for-profit organisation cannot rely on this information regularly. Informal information holds usefulness, yet it does not hold authority or timely expertise for not-for-profit organisations to rely on entirely.

\subsubsection{Archives New Zealand Standards}

Archives New Zealand is the national organisation that oversees archives and recordkeeping in New Zealand. It also holds a regulatory role, as per the Public Records Act 2005 (Archives New Zealand, 2020a). The purpose of these standards to enable government organisations to fulfil their requirements under the Public Records Act 2005. In records management policies and guidelines, fullness and accuracy have been the most frequently demanded of records (Yeo, 2018). These standards of planning and strategy, implementation, and key obligations (Archives New Zealand, 2020a) have been developed from the records lifecycle and continuum theory. The value of these standards is that they hold usefulness regardless of organisation type.

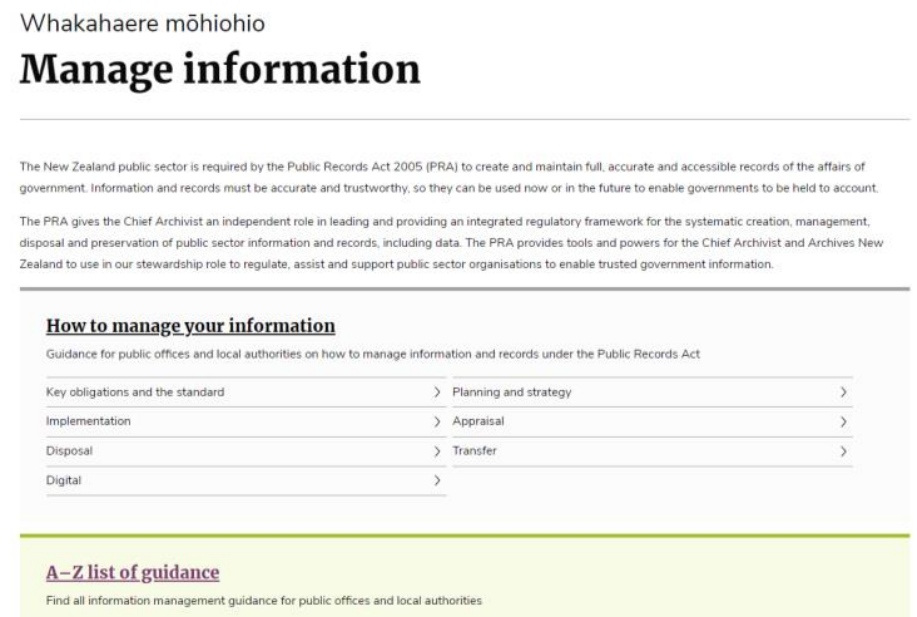

Figure 1: Manage information. (Archives NZ, 2021)

Government organisations require a records manager (Archives New Zealand, 2014) to fulfil records management governance legislation. These records managers would know which legislation applies and enforce best practice in record keeping. From 2020 to 2021 (Figure 1), the website has reformatted, making the format more user-friendly. (Archives New 
Zealand 2021) Services are available for government organisations. Archives New Zealand employees can coach the knowledge of records theory, such as the records lifecycle and records continuum. A business would have to employ a records manager to adapt recordkeeping standards. Several volunteers mentioned the frustration of no standards to assist with record-keeping (Hill, 2016; Crawford, 2018). There are still no standards or assistance developed directly for not-for-profit organisations.

\begin{tabular}{|c|c|}
\hline Organisation & Standards and Services \\
\hline $\begin{array}{l}\text { International Standard } \\
\text { Organisation (ISO: 15489-1:2016); } \\
\text { International }\end{array}$ & $\begin{array}{l}\text { - An international standard that covers information and } \\
\text { documentation related to Records Management (Shepard \& } \\
\text { Yeo, 2013) } \\
\text { Define concepts and principles relating to: } \\
\circ \text { Records metadata } \\
\circ \text { Policies, responsibilities, training and monitoring } \\
\circ \text { Business analysis + records requirements } \\
\circ \text { Records controls }\end{array}$ \\
\hline $\begin{array}{l}\text { National Archives, } \\
\text { Charity Commission; United } \\
\text { Kingdom. }\end{array}$ & $\begin{array}{l}\text { - No standards record-keeping for not-for-profits organisations } \\
\text { (The National Archives, 2019). } \\
\text { - No publicly available standard for charities to follow. } \\
\text { There is a close relationship between the charities } \\
\text { commission and the National Archives (Charity Commission, } \\
\text { n.d.). }\end{array}$ \\
\hline $\begin{array}{l}\text { Library and Archives Canada, } \\
\text { Corporations Canada; Canada. }\end{array}$ & $\begin{array}{l}\text { - The focus is on government agencies (Libraries and Archives } \\
\text { Canada, 2021). } \\
\text { - Not-for-profit corporations require registration (Corporations } \\
\text { Canada, 2013). } \\
\text { - They listed reporting obligations to assist corporations with } \\
\text { financial information only (Corporations Canada, 2013). }\end{array}$ \\
\hline $\begin{array}{l}\text { National Archives of Australia } \\
\text { [NAA]; Australia }\end{array}$ & $\begin{array}{l}\text { - A national standard to records management. (NAA, 2021d) } \\
\text { - Standards are created for government organisations to } \\
\text { develop a records policy (NAA, 2021c) } \\
\text { - } \quad \text { The policy is then evaluated by the NAA (NAA, 2021d) }\end{array}$ \\
\hline $\begin{array}{l}\text { Archives New Zealand; New } \\
\text { Zealand }\end{array}$ & $\begin{array}{l}\text { - } \quad \text { Resources and guides developed for government agencies } \\
\text { - No individual standards created for not-for-profit } \\
\text { organisations. } \\
\text { - } \quad \text { No services are available for not-for-profit organisations. }\end{array}$ \\
\hline
\end{tabular}

Table 3: Summary of International and National Standards.

\subsubsection{Accounting Standards}

In New Zealand, all charities create annual financial and performance reports to Charities Services (2021b). The external reporting board (XRB), as a government organisation, has created four tiers of standards to be completed annually (Charities Services, 2021b). The default for all charities is tier 1 (Figure 2), and following two years of financial information can then justify moving to a different tier (Charities Services, 2021c). However, an immediate issue is that these standards are not compulsory for trusts and incorporated societies. As they are 
voluntary, not for profit organisations are not held to the same standard, and the general population can question their transparency.

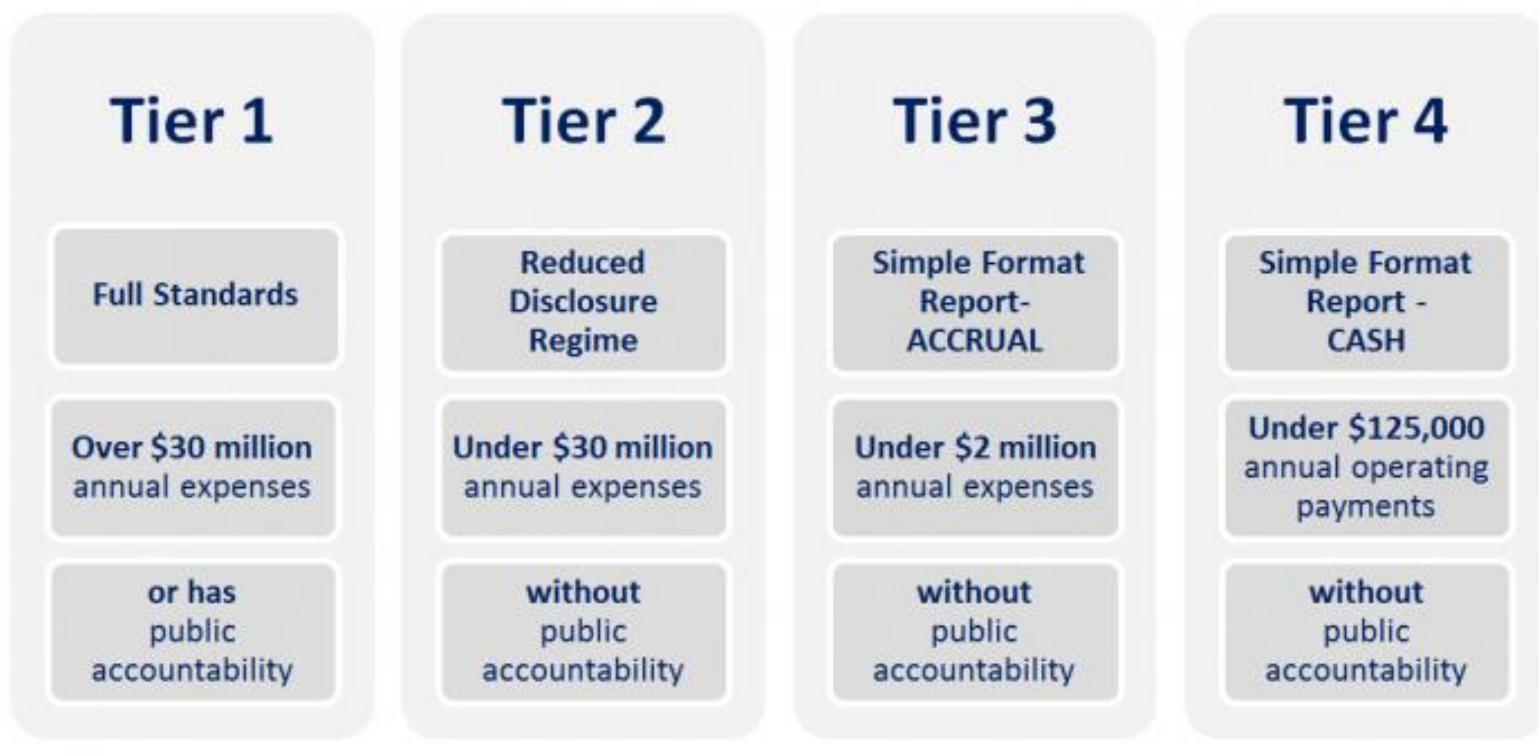

Figure 2: Summary of Accounting Tiers (Charities Services, 2021)

\subsubsection{Professional Organisations}

For New Zealand, there is an existence of Professional organisations such as ARANZ and RIMPA. They are a body of professionals that apply records management theories to a government and business context. The record-keeping standards in New Zealand were created for government organisations; most of the studies focus on the role of records management practices in organisations. Normative theory assists researchers by providing a value-based view about how the world works logically (Velasquez, 2008). The application of normative theory from Oliver and Foscarini as well as Klett will show the academic success or failure of records management. Oliver and Foscarini (2020) summarises behaviours, attitudes, and resources that results in the success of a records management programme. In other words, if there is positive support for record-keeping standards, it will be successful. On the contrary, Klett (2019) acknowledges that records management knowledge may be ignored from a deficit of competencies in business operations. It will concern records managers, as a lack of archival material would harm the organisations' future.

This literature review proves that records management theories such as the records lifecycle and records continuum hold great importance. The literature of community archives also holds importance, as issues in community archives stem from poor records management. The theoretical body of knowledge allows us to apply social theory (Bachman \& Schutt, 2021) to record-keeping standards worldwide, including Australia and New Zealand. Within New Zealand, the DIA developed the Community Archive as an information base for not-for-profit organisations but failed to update information. The lack of standards and professional 
organisations is entirely unaware of the current practice and if the Archive New Zealand Standards assist not-for-profit organisations. 


\section{Research Questions}

A review of the literature related to records management has clarified there has been no specific research on record-keeping for not-for-profit organisations and whether the standards issued by Archives New Zealand meet their needs.

RQ1: What is the current practice for New Zealand not-for-profit organisations managing records?

RQ2: How do New Zealand clubs and organisations use the existing record-keeping documentation set out by Archives New Zealand?

\subsection{Research Design}

The strategy is to use applied research, which expresses the goal of going beyond knowledge production towards situation improvement (Leedy and Omond, 2016). This research contributes to positive change by enabling professional organisations and a state agency to deliver a solution to not-for-profit organisations. There is no existing direct data source from Archives New Zealand. An online survey will determine the current practice and identify the value of record-keeping standards from not-for-profit organisations. The design enables gathering data from a wide range of respondents from not-for-profit organisations in New Zealand.

\subsection{Research Method}

This research project is intended to identify the current practice and extent of Archive New Zealand standards' usefulness. Quantitative research is an objective positive search for a singular truth that relies on statistics on a large scale (O'Leary, 2017). Quantitative data collection and analysis also enables descriptive comparison (Lewis-Beck, Bryman \& Futing, 2004) by factors of opinion to assess the reliability of current standards. As no primary data exists to fulfil these research questions, data collection was collected through a survey. Survey research involves acquiring information about one or more people, their opinions, and previous experiences by asking them questions and tabulating their answers. The goal is to learn about the current situation by surveying a population sample (Leedy and Ormond, 2016). This method choice enables gathering data from a wide range of respondents from not-for-profit organisations in New Zealand.

The survey ran for four weeks, from the 16th of April to the 16th of May 2021.

\subsection{Population and Sample}




\subsubsection{Not for Profit Organisations}

In New Zealand, three main types of organisations exist. The government provides goods and services to usually fulfil its political, regulatory, and service delivery roles (Statistics New Zealand, 2018). Businesses also provide goods and services, mainly to profit individuals or shareholders (Statistics New Zealand, 2018). From the definitions, this research concludes that not-for-profit organisations comprise Charities, Incorporated Societies, and Trusts (Table 4). As they work for the common good, not-for-profit organisations do not have profit-making as a goal, do not distribute any profits to their members, and often rely on volunteers providing free labour and resources to operate successfully (Statistics New Zealand, 2018).

\section{Charities}

- Common intention of providing the best possible outcomes for their beneficiaries (CommunityNet Aotearoa, 2014).

- There are more than 27,000 charities registered (Charities Services, 2021a).

- An effective charity is clear about its beneficiaries' needs, charitable purposes and vision, and uses this knowledge to guide its decisions and activities (CommunityNet Aotearoa, 2014).

Incorporated Organisations

-Incorporated Societies has its own legal identity, separate from its members (New Zealand Companies Office, 2019).

- One type of incorporated society is a sports club, in which an association of people come together for a common goal, usually joint supported and meets periodically (Clubs New Zealand, 2020).

\section{Trusts}

- Created to as an ongoing orgnisation to protect assets.

-Involves a Settlor, Trustee, and beneficaries.

Table 4: Subsets of Not-for-profit organisations.

Classification of non-profit institutions from the non-profit institutions' satellite account (Statistics New Zealand, 2018):

- They are organised to the extent that they can be separately identified from businesses and the government.

- Several organisations exist as a not for profit organisation, but there is oversight by local or national government entity.

- This 'extended arm' link does not mean they directly do not fall under the Public Records Act 2005.

- Do not distribute any surplus they create, thus not for profit.

- Are institutionally separate from government, as a charity or incorporated society. 
- As the board or members create decisions for the organisation, this puts them in control of their operations.

- The ordinary person does not have to be a member, and members' input is not compulsory.

\subsubsection{Sampling}

Ideally, randomisation is used to collect data to represent the population of not-forprofit organisations correctly (Leedy \& Ormrod, 2016). A purposive sample was applied to produce a sample that closely represents the population (Lavrakas, 2008). Several secondhand sources were utilised as the geographic distribution, and the sample population do not exist on one single database (Table 5). One main factor was the Unsolicited Electronic Messages Act 2007, which states contact details from the Charities Services and the Incorporated Societies Register to be used (Charites Register 2021a; New Zealand Companies Office, 2019).

A search query using a google search engine with the keywords "New Zealand not for profit" revealed publicly available websites. These websites held a list of names of not-forprofit organisations. Exploratory searches were completed with the name of the organisation to locate and email address. Obtaining the not-for-profit organisation data required collection from the following elements:

\begin{tabular}{|l|l|l|}
\multicolumn{1}{|c|}{$\begin{array}{c}\text { Excluded source of } \\
\text { Organisations }\end{array}$} & \multicolumn{1}{|c|}{$\begin{array}{c}\text { Included Source of } \\
\text { Organisations }\end{array}$} & \multicolumn{1}{c|}{ Group size. } \\
\hline Charities Register (2021a) & & 27,000 \\
\hline $\begin{array}{l}\text { Incorporated Societies Register } \\
\text { (New Zealand Companies Office, } \\
2014)\end{array}$ & & 7,800 \\
\hline & 4good Charitable Trust (2019) & 96 \\
\hline & Sport New Zealand (2021a) & 138 \\
\hline & A Memory Tree (2021) & 229 \\
\hline & Spend my Super (2021) & 11 \\
\hline & Not for Profit Resource (2020) & 264 \\
\hline & Wikipedia (2016). & 33 \\
\hline & Urban List (2018) & 8 \\
\hline
\end{tabular}

Table 5. Community Organisation survey size.

\subsection{Instrument / Survey}

The survey instrument was chosen to ensure confidentiality, and statistically significant results were calculated to show reliability, validity and generality (O'Leary, 2017). As this design has established the need to collect a large quantity of information, survey techniques 
are needed to capture the reality of human populations (Leedy and Ormond, 2016). The survey software Qualtrics was offered through Victoria University of Wellington (2021). As no primary nor secondary data existed to answer the research questions, it was necessary to conduct a survey. A pilot survey for three participants was sent to them on March 11th, and the language was simplified in line with feedback. An amended version was used in the final survey.

\begin{tabular}{|l|l|}
\hline Participant Consent & Q1 \\
\hline Screener Question & Q2 \\
\hline Current Practice & Q3, Q4, Q5, Q6 \\
\hline Archive New Zealand Standards & Q7, Q8 \\
\hline Demographic Questions & Q9, Q10, Q11, Q12, Q13, Q14 \\
\hline
\end{tabular}

Table 6: Survey Questions relating to research questions.

The survey was divided into four sections (Table 5). The first section contained permission to collect information and a screener question to ensure that people involved with governance, the management or administration were the participants in the survey.

The second section measured current attitudes towards records management. Some questions were adapted from Oliver and Foscarini (2014), and others were gleaned from information found while completing the literature review. Attitudes toward records management used a 5 point Likert scales. Qualtrics software enabled the choices to be consistent to assist with survey completion. The last statements regarding the amount of trust in the organisation current records policy. Participants that did not somewhat or strongly agree were directed to Q4 and probed further to find what difficulties they were currently having. Q5 focused on discerning what current habits participants had regarding record-keeping. Lastly, to help identify current knowledge and familiarity of legislation, a 4 point scale was used, starting from awareness to applying the listed legislation found during the literature research.

The middle section, which relates to research question 2, showed screenshots of principles 1 and 2 of the current record-keeping standard. A reference was listed below each principle, so participants could copy and paste the link if they wanted to read the entire standard for later. These open text questions allowed the opportunity to collect qualitative data, targeting whether the standard is simply good enough and asking not-for-profit organisations directly whether they want standards or not. These allowed the respondent to describe their needs in detail. 
The last section was made up of five multi-choice questions and one constant sum question (Thomas, 2017). These questions focused on the demographic variables of a notfor-profit organisation, including the sector, the balance of paid employees and volunteers, the organisation's total size, the organisations location in New Zealand, how long the organisation had existed, and how long the participant worked within the organisation.

\subsection{Data Collection}

After compiling contact information and uploading data to Qualtrics, anonymous email link-sharing was sent. The researcher also compiled Twitter, Facebook, and Linkedin posts with an anonymous link directing participants to the survey. Participants will then click on the link to the information sheet, then start the survey. Data from surveys that indicate a person was not interested in cooperating will be ignored because then it creates a bias in the data delivered (O Leary, 2017). Due to the nature of distribution, units of analysis in surveys will be per organisation, with shared characteristics.

Chosen participants should be involved with the creation and maintenance of records. The researcher assumed they either following a process or finding difficulty managing their records. Analysis of the data has occurred after the $16^{\text {th }}$ of May, the closing date of the survey.

\subsection{Data Analysis}

As a survey held open and closed-ended questions, different analysis methods will be applied to analyse the data given by participants. Qualtrics software was used to collect and view basic information. The results themselves discern whether the records life cycle and records continuum theory still apply within a not-for-profit context. Qualtrics software also generated descriptive statistics from the data and allowed researchers to download responses from participants. This allows for further analysis to create the mean, the median and the average (Leedy and Ormrod, 2016). The identified information removed from data, further interpreted in statistical formats, and analysis with discussion followed.

For the following results, descriptive statistics will be used as much as possible. The statistical analysis describes what the data looks like to the user (Leedy \& Ormrod, 2016). Inferential statistics will be applied as needed. Due to the purposive sampling method, and the small sample size, the results are not generalised across not-for-profit organisations in New Zealand. The total population of not for profit organisations is estimated to be more than 150 630, as that was the calculated population three years ago from Statistics New Zealand (2018). 


\subsection{Ethical Considerations}

The study was designed to be hazardless and holding no physical risk to participants. A participant information sheet (Appendix 2) gave the rationale for the survey, including what occurs with the data collected and the dissemination of the research project. An anonymous survey will allow participants to respond honestly, as their response will not be associated with them (Leedy \& Ormrod, 2016). Informed consent is in the form of the first question. Questions were designed to identify information not given in the survey, allowing the researcher to analyse the data objectively. Psychological harm was minimised by avoiding posed questions, thus not judging participants (O'Leary, 2017).

Data were de-identified to ensure no opportunity to contact individuals participating in the survey (Thomas, 2017). This eliminated the option of post participation debriefing. The researcher and supervisor are the only two people who have access to the survey collection's raw data (Thomas, 2017). To ensure privacy, specific steps were made, including deleting exported data after two years. The study was approved by the Victoria University of Wellington Ethics Committee as application \#29244 (Appendix 1). 


\section{Results}

Five hundred and eighty distributions over email were sent out and anonymous links through Facebook, Twitter, and Linkedin posts. Sixty-three surveys were started, leading to forty-three completed responses. Three people did not pass the screener question, as they were not involved in the administration, management or record keeping of their organisation. The researcher received two unsolicited email responses and twenty incomplete responses, all of which have been excluded from the analysis.

A partial completion (breakoff) is characterised by time or place dependency (O'Leary, 2017). After a certain point within the survey, data is missing. Partial completions mainly occur in online surveys. There are two main places that participants completed break off in the survey, one was the questions about current practice (Q4) and the other place was at the legislations (Q5). An important indicator of data quality is missing data (O'Leary, 2017). To avoid bias, incomplete results were removed. This allows the following findings to be validated further.

\subsection{Demographic Results}

When analysing the results, it is appropriate to analyse the demographic spread of those who completed the survey first. This section contains discrete variables (Leedy and Ormrod 2016), so this information will not be compatible with the continuous data shown in Statistics New Zealand (2018). Of the 40 currently completed surveys, contained the following demographic information:

\section{Type of Organisations}

Most respondents work within multiple sectors. Forty respondents chose multiple answers; as they felt as they fitted in multiple categories. From a total of $71,32.39 \%$ identified with the community/social services sector. Another $15.49 \%$ identified with education/training/research and $15.49 \%$ with health, people and disabilities (Table 20). Interestingly, these last two percentages correlated precisely.

Comparing these results with classifications from Statistics New Zealand (2018) in Table 21, We see the highest amount of not-for-profit organisations belong to the culture, sport and education $(51,820)$, followed by social services $(14,130)$. Comparing this to the resulting demographic sectors from $Q 9$, community and social services are higher than culture, sport and recreation. This change in sector priorities is interesting, as there is a stronger focus on community services.

\section{Balance of employees and volunteers}


For the balance of full-time, part-time, and volunteer staff in an organisation, trust was placed in Qualtrics software to manage the numbers inputted by participants to add up to 100 . Several participants had created outliers in the data by inputting fewer employees and an excessive number of volunteers (Table 22). The extreme case was that one respondent chose to have 14,000 volunteers in their organisation, which caused a large issue.

Using inferential statistics (Thomas, 2017), we can tell that there is a positive skew, as the mean of each field is more significant than the mode. This clearly shows that the distribution of data for this question is not normal, and as the outliers are present, most of the data is held in the tails of the distribution. (O'Leary, 2021). Ideally, the numbers would add up 100 to confirm a general breakdown. The issue here is that not all respondents' answers added up to 100; thus unreliability is confirmed with the outliers in the data (Table 7).

\begin{tabular}{r|r|r|r|r|r|r|r|} 
Field & Minimum & Maximum & Mean & Mode & $\begin{array}{r}\text { Standard } \\
\text { Deviation }\end{array}$ & Variance & Count \\
\hline $\begin{array}{r}\text { Full time (35 - 40 hours } \\
\text { per week) paid } \\
\text { employees. }\end{array}$ & 0.00 & 85.00 & 12.72 & 0 & 22.80 & 519.65 & 40 \\
$\begin{array}{r}\text { Part-time (less than 44 } \\
\text { hours) paid employees. }\end{array}$ & 0.00 & 100.00 & 14.85 & 1 & 21.21 & 449.98 & 40 \\
\hline $\begin{array}{r}\text { Any time (any number of } \\
\text { hours) volunteers }\end{array}$ & 0.00 & 14000.00 & 412.65 & 0 & 2179.23 & 4749052.73 & 40 \\
& \\
& Table 7: Q4 - Inferential Statistics.
\end{tabular}

The findings of the number of employees in a not-for-profit organisation differ from national data. Again with a comparison from Statistics New Zealand (2018) in appendix 4, this research has added the amount of part-time and full-time employees from Q10, allowing a comparison of data. This research distribution is weighted toward fewer employees, especially the categories of 1 to 5 employees and 6 to 19 employees. Interestingly, the data from Statistics New Zealand reported that more organisations reported having 0 employees. This result confirms that not-for-profit organisations have more volunteers than employees.

\section{Size of not-for-profit organisations}

For the size of respondents' organisations, less than the 50th percentile contains $65 \%$ of the respondents' choice. This is derived from the fact that $37.5 \%$ chose between 11 to 50 people, $27.5 \%$ chose less than ten people (Table 24). We conclude that organisation sizes are small, as this confirms with the data collected from the previous question.

\section{Provinces of New Zealand organisations}


For the locations of not-for-profit organisations in New Zealand, The most prominent result come from $22.22 \%$ in Auckland, followed by $17.28 \%$ in Wellington (Table 25). The result shows that not-for-profit organisations are focused on two main centres in New Zealand. It is interesting to note that other provinces ranged from 2 to 7 organisations.

\section{Duration of Existence}

For the length of existence of non-profit organisations, the data from this question is located in the upper percentile. 57.5\% of organisations have existed for 21 or more years (Table 26). 20\% stated $10-14$ years, and $7.5 \%$ from 0 to 4 years, 5-9 years, and $15-20$ years equally.

\section{Duration of Involvement}

Lastly, for the length of time participants were involved with their current not-for-profit organisation, $37.5 \%$ of respondents have been involved in their not-for-profit organisation between five to nine years, with $35 \%$ of respondents have been involved less than four years (Table 27). It looks concerning that the minimum of $5 \%$ hangs around the 10 to 14 -year range. It shows the trend of people being involved until ten years, then leaves the not-for-profit organisation.

\begin{tabular}{r|r|r} 
Answer & $\underline{\%}$ & $\underline{\text { Count }}$ \\
\hline $0-4$ years & $35.00 \%$ & 14 \\
\hline $5-9$ years & $37.50 \%$ & 15 \\
\hline $10-14$ years & $5.00 \%$ & 2 \\
\hline $15-20$ years & $12.50 \%$ & 5 \\
\hline $21+$ years & $10.00 \%$ & 4 \\
\hline Total & $100 \%$ & 40 \\
\hline
\end{tabular}

Table 8: Years involved in a not-for-profit organisation.

\subsection{Current Practice Results}

This set of data was collected at the earliest point of the survey, allowing attitudes and knowledge of records management to be collected. Ordinal data can be collected from Likert scales (Leedy and Ormrod, 2016). The Q3 first defined records management, so participants would not be confused with knowledge management theory (Appendix 3, Q3). This allows participants to become familiar with the depth of records management. 


\section{Attitudes towards Records Management}

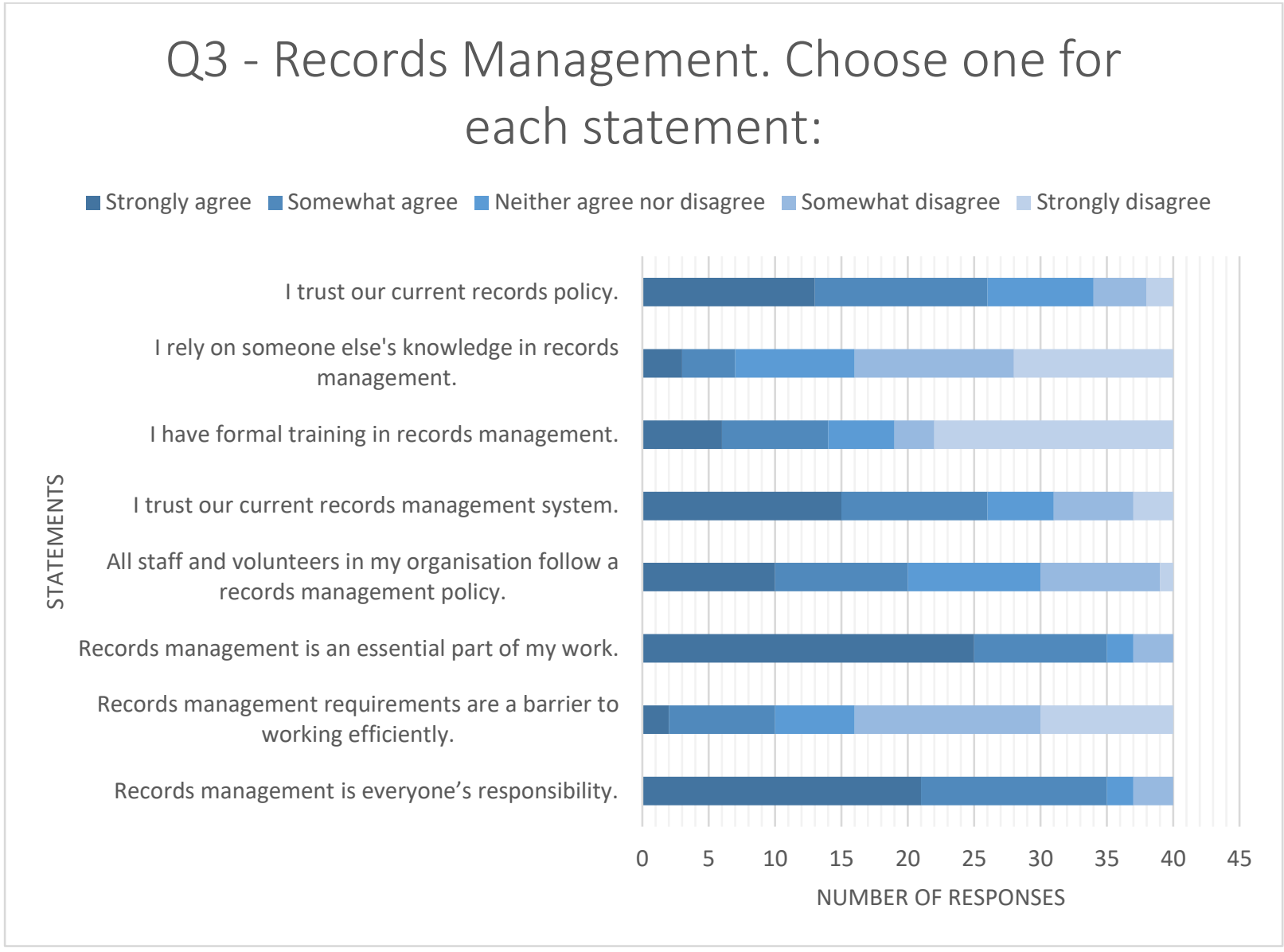

Figure 3: Graph of Records management attitudes.

Most participants strongly believed that records management is everyone's responsibility and is an essential part of their work. The participants strongly disagreed with having formal training themselves. They also strongly disagreed with relying on someone else in records management (Table 11). Out of the 40 participants, 16 respondents did not have complete faith in the records policy in their organisation. When probed further (Q4), 31\% did not know their records policy, and another $31 \%$ had additional comments (Table 13). These themes aligned with not having a records policy, and if one was created, issues with the organisation's culture to accept the records policy.

\section{Current / Not Current Practice}

For the acceptance and rejection of various practices, the survey question was designed to avoid leading respondents and give them various habits to choose from. 
The most positive habits were described looking for ways to improve their record process and archiving printed material appropriately. It is interesting to note a more substantial bias towards digitisation, as there is less printing and more filing of electronic material (Table 14). The fact that respondents have a lower chance of ignoring physical and electronic documentation gives researchers confidence that notfor-profit organisations follow appropriate processes.

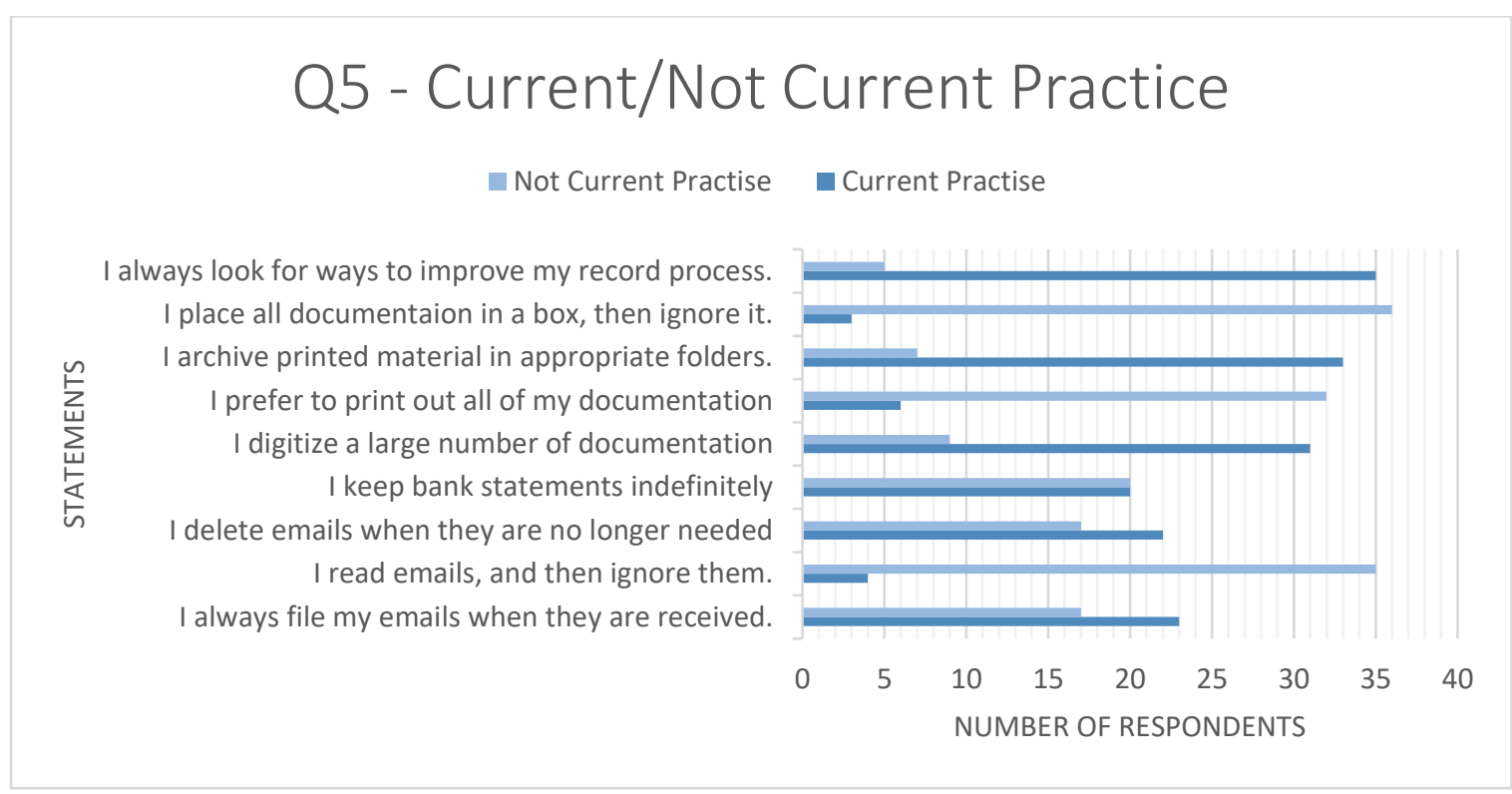

Figure 4: Graph of current and not current practices.

\section{Current Legislative Knowledge}

For the present knowledge, participants were asked to choose a statement related to how they use several pieces of legislation. Most respondents applied the Charities Act 2005 (49\%), Privacy Act 2003 (54\%), Incorporated Societies Act 1905 (41\%) and Income Tax Act 2007 (39\%) to their organisation. The best awareness was of the Official Information Act 1982 (39\%). As the sum of responses does not add up to 40 (Table 15), it is clear that not all respondents chose an option for each statement, with three respondents omitting the question altogether. Due to the Trusts Act 2019 $(47 \%)$ being not relevant to most organisations, there is a strong idea that not enough trust organisations took the survey. 


\subsection{Standard Results}

$\underline{\text { Record-keeping standards application to a not-for-profit organisation }}$

The purpose of Q7 was to find how participants would currently apply place themselves in the context of not-for-profit organisations. Showing participants a picture of the current records management standard (Archives New Zealand, 2016), participants were allowed to choose multiple responses. Of the total count (96), $29.17 \%$ chose that the language is simple to understand. Also, $26.04 \%$ believe that the minimum requirements are achievable. This shows confidence in the current records management standard issued by Archives New Zealand.

\begin{tabular}{|c|c|c|}
\hline Answer & $\%$ & Count \\
\hline The language is simple to understand. & $29.17 \%$ & 28 \\
\hline The minimum compliance requirements are achievable. & $26.04 \%$ & 25 \\
\hline We currently are following the following principle. & $16.67 \%$ & 16 \\
\hline We would require a records manager to understand these principles. & $3.13 \%$ & 3 \\
\hline We would need further training to understand these principles. & $10.42 \%$ & 10 \\
\hline $\begin{array}{r}\text { We would need more funding to have a specialised person to follow these } \\
\text { principles. }\end{array}$ & $14.58 \%$ & 14 \\
\hline Total & $100 \%$ & 96 \\
\hline
\end{tabular}

\section{Evaluate Archives New Zealand Standards}

For Q8a and Q8b, participants were shown principle two from Archives New Zealand (2016). Q8a asked, 'What concerns do you have about these current standards', and Q8b asked, 'Do you think there should be a general record-keeping schedule for New Zealand'. Only 35 respondents answered Q8a, and only 39 respondents answered Q8b (Table 17). Responses included:

- There needs to be more accountability and consistency across the board.

- For a general record-keeping schedule for not-for-profit organisations within New Zealand:
- Yes, from 22 respondents $(56.4 \%)$
- No, from 9 respondents $(23 \%)$ 
Concerns included:

- No concerns from 11 respondents (31.4\%).

- Record-keeping standards should not be compulsory.

- Applicable standards are needed.

- Different organisations have to follow multiple legislative requirements, all records are kept for 7 years just in case.

- Some organisations currently hold no records policy and are noncompliant with principle 1 (Archives New Zealand, 2016).

- Record-keeping principles would be an extra burden for complying, thus becoming a nuisance.

- As standards are designed for organisations, the language is not simple enough for many volunteers and administrators.

- The standards are not well known thus, and time and effort would be needed to implement them.

- This leads to an extra cost to not-for-profit organisations

- They are not straightforward as accounting standards, which are separated into different tiers.

\subsection{Discussion}

New Zealand not-for-profit organisations assist New Zealanders in providing health, education, and social services to promote culture and civic action (O'Brien, Sanders \& Tennant, 2009). Starting with demographic results, most New Zealand not-for-profit organisations have existed for more than 21 years, with most staff being a part of them for less than ten years. Combined with the large proportion of volunteers, there is a loss of knowledge. Combining this with a lack of standards, most not-for-profit organisations are not fully serving the country.

\subsubsection{Current Practice}

Stating the first research problem: What is current practice in New Zealand not-for-profit organisations.

The results indicate that participants have high confidence in records management. The statements, current practice, and knowledge of legislation requirements are favourable. Participants showed that records management is everyone's responsibility and that records management requirements are not a barrier to working efficiently. As records management is an essential part of their work, it gives us confidence (Shepard and Yeo, 2013; Oliver and Foscarini, 2014) that the behaviour of employees in not-for-profit organisations trusts records 
management. The result also came through strongly through incomplete respondents (Q3 and Q4), reinforcing the findings. As $77.5 \%$ of respondents choose to digitize their documentation, this proves that the records continuum is accepted over the records lifecycle theory. However, $45 \%$ of respondents have no formal training in records management. As the records lifecycle and records continuum theories are still unknown, this suggests that not-for-profit organisations that hold social accountability do not have a record-keeping policy.

\subsubsection{Application of Theory}

The social theory allows us to record life cycle theory and the records continuum theory to relate possible observations (Bachman \& Schutt, 2021). If records management is not followed, there is a danger of harming the organisation's integrity and legal liability by not fulfilling legislative requirements (Explora - Australia/New Zealand, 2013; Not-for-Profit NZ, 2013). Even as the environment of not-for-profit organisations differs from government and business organisations, we can apply research from different organisation types to build a better picture. None of the respondents mentioned standards from other countries, such as the ISO or National Australian Archive. This reaffirms a lack of knowledge from governance, management, or administration employees in not-for-profit organisations (Hill 2016).

Similarly, the standards from New Zealand Archives are also not well known. Shepard \& Yeo (2013) and Oliver and Foscarini (2020) discuss the importance of an environmental analysis. The geographic location of the organisation and the legislative requirements, formal structure, and existing procedures need to be taken into account (Shepard \& Yeo, 2013). Further observations will correctly identify current approaches to record-keeping. Thus Archives New Zealand will need to make further analysis (Shepard \& Yeo, 2013). This research fulfils a gap for not-for-profit organisations, as there is no targeted standards or framework to apply.

\subsubsection{Community Archives}

Flinn (2007) describes community archives as the grassroots activities of holding records about community heritage. Multiple researchers emphasise the need to overlook ephemeral nature to document a community's experience fully (Copeland, Lipinski, \& Jones, 2017). The variety of sectors that not-for-profit organisations vary widely, but they all operate to help people in New Zealand. Community archives become mediators between professional heritage services and community groups (Stevens, Flinn, \& Shepherd, 2010). Records managers can assist not-for-profit organisations with their knowledge base. Thus success depends on genuine commitment and engagement with the community in question (Stevens, 
Flinn, \& Shepherd, 2010). Education and support can fully enable not-for-profit organisations to achieve transparency and accountability.

To avoid these issues, managers and volunteers of not-for-profit organisations could engage with community archives in New Zealand. Socialised behaviour lies behind the decision to create records. Thus there is a division in the purpose of each record (Shepard \& Yeo, 2013). A theme from Q8 is that record-keeping differs between each person, and some organisations only keep records for seven years to comply with one legislation. An opportunity for not-for-profit organisations is to store records such as photographs in an archive. The gap between standards and practice is fulfilled (Edney, 2009), as a community archive is a form of activism (Flinn, Stevens \& Shepard, 2009), which will allow some organisations will have more prominent voices than others (Schwartz and Cook, 2002). As Australia leads with knowledge sharing and available assistance, difficulties lay with The Community Archive (ARANZ, 2021). Table $\mathrm{x}$ lists two national organisations that offer services. Engagement with community archives will eliminate wasting resources, time, or money to locate documents and keeping records that should otherwise be destroyed. (Explora New Zealand, 2013).

Alexander Turnbull Library

(National Library, 2016)

- Donation/bequest/legal deposit, with an option to engage with the consultation.

- An ongoing priority list for donations.

- Assistance from National Preservation Office:

- Assessment/ advice service.

- Vague scope and condition of content.
Te Papa Tongawera (2016)

- Mātauranga Māori histories and cultures

- The natural environment of New Zealand

- New Zealand art and design

- The culture of Pacific peoples in New Zealand, the Pacific rim and in their contemporary locations;

- New Zealand histories, cultures and peoples in a national and global context.

Table 10: National Organisation Services.

\subsubsection{Archives New Zealand Standards}

How do New Zealand not-for-profit organisations use the existing record-keeping documentation set out by Archives New Zealand?

The results indicate that not-for-profit organisations need the creation of simplified standards is needed. $56.4 \%$ of respondents want standards, as they believe it will provide accountability and consistency. Additional confirming respondents want better policy and frameworks. Currently, several respondents were concerned they are currently not meeting 
principle 1, enforcing the concern of not-for-profit organisations unable to have a mutually respectful working relationship (O'Brien, Sanders \& Tennant, 2009). For the current standards, $29.17 \%$ of respondents believe the language is simple enough to understand. However, several respondents emphasised a large number of volunteers, reinforced by table 22 . As volunteers vary in knowledge base and skill set, there is no guarantee that these current standards will be satisfactory.

In contrast, $23 \%$ of respondents rejected the notion of record-keeping standards from human resources and cost concerns. Theme mapping (Thomas, 2017) will overlook the remainder of outlying concerns from not-for-profit organisations. One concern is funding and financial issues, as that affects a not-for-profit organisations' ability to have been widely identified as critical issues for all parts of the sector (O'Brien, Sanders \& Tennant, 2009). Archives New Zealand currently supports government organisations, yet the body of records management knowledge still applies to not-for-profit organisations. As suggested by O'Brien, Sanders \& Tennant (2009), discussion and consultation exercises from central and local government can become complex bureaucratic processes. To mitigate concerns, a proposal is to collect focus groups containing representatives from the charities commission, incorporated societies, and various organisations that serve the public. Not-for-profit needs can be identified before standards are created.

\subsubsection{Records Managers}

Another source of knowledge comes from the professional organisations of RIMPA and ARANZ. As professional organisations, they aim to promote the understanding and importance of records and archives in New Zealand and Australia. Applying the records management theory is extremely difficult for an untrained volunteer in a not-for-profit organisation. They hold power to create and effect good practice by providing a better overview and structure to develop strength in the New Zealand community (Klett 2019). One way to influence change is to shift what is essential and create engagement with sectors (Oliver and Foscarini, 2014). Funding limitations affect service provision, leading to a small pool of experienced staff (O'Brien, Sanders \& Tennant, 2009). Thus ongoing education and training are needed. Collaboration is needed between records managers and organisations, as there are issues of the knowledge gap and staff awareness, and information technology departments (Duis, 2014; Gradwell, 2015). Ketelaar (2005) agrees that knowledge should be shared to gain understanding. Opportunities lie in the communication of the NZ Navigator Trust (2021d) to interact directly with Charities Services. If this grows into a culture that does not accept records management, it will be hard to achieve standards (Gradwell 2015). Thus, the body of knowledge of records management will be lost to not-for-profit organisations. 


\subsubsection{Accounting Standards}

Several respondents mentioned that charities now have four tiers of accounting standards to comply with, depending on the funding and responsibilities of the organisation. From generally accepted accounting principles, charities initially thought that the financial return measured the only thing that the world wanted to hear from them (Baskerville \& Servalli, 2016). Charities argue that their performance is based not only on financials but also on government organisations' financial support. The standards hold open access, and training provided to assist charities. Other not-for-profit organisations can adapt these to help them prepare their financial statements, yet this does not cover all records as a records policy can. 


\section{Limitations}

\subsection{Research Method}

This study applied to a large number of organisations that had publicly available information online. The results show no spread over the country as most of the respondents was from Auckland or Wellington. In addition, classified categories differed from Statistics New Zealand (2018). Flawed data shown proves the need for a professional body to complete more research to validate findings. As two sets of data do not match, the weight from the distribution sample is possible to be dismissed. As Statistics New Zealand holds more reliable data combined with the errors from respondents, the demographic material is unreliable due to purposive sampling. A mixed-method analysis would be desirable to confirm the current practice of not-for-profit organisations. As observations or several case studies, a researcher can approach several large organisations. A secondary reason for having a mixed-methods approach can benefit from a better understanding of records management. Two emails from respondents questioned the validity of the survey. As non-records managers, their education and knowledge base differed from the researcher.

\subsection{Further Research}

As the results will only indicate to what extent record-keeping standards are needed for community organisations, there is an enormous opportunity to undertake further research in the field of records management theory. They are as follows:

- The role of Community Libraries and Archives is to share the role of storage and maintenance. It opens the question of whether the material fits within the scope or will Public Libraries of New Zealand fill the knowledge gap.

- To what extent will community archives care about record-keeping standards for New Zealand sports clubs and organisations.

- For user education, are community archives willing to assist community organisations run by volunteers?

- Under what circumstances should New Zealand archivists and records managers create and deliver simplified standards for New Zealand clubs and organisations. 


\section{Conclusion}

Due to a lack of standards, New Zealand not-for-profit organisations offer no structure to keep adequate records. Charities, Incorporated Societies, and Trust organisations are ignored, left like ships within the sea without a lighthouse. Archives New Zealand has withdrawn support from community archives that negatively affected not-for-profit organisations. Thus a short term solution is for not-for-profit organisations to engage with community archives. ARANZ (2021) found that ongoing funding and support needs to continue for The Community Archive. Results showed that the current practice of not-for-profit organisations is comparable with government and businesses. In addition, 56.4\% of respondents want standards from Archives New Zealand to be developed for not-for-profit organisations. A long term solution is to create simplified standards, followed by education and training led by professional bodies. This follows created accounting standards for charities and achieves transparency and accountability. Additional research and engagement will need to commence to satisfy additional concerns from respondents. 


\section{References}

4good Charitable Trust (2019). Charities we've supported so far.

https://www.4good.org.nz/charities/charities-we-have-supported/

A Memory Tree. (2021).Major Charities in NZ - lists and links to leading charity groups. https://www.amemorytree.co.nz/donate_to_charity.php

Anderson, K. (2007). Evidence and memory: records services and archives. Libraries in the Twenty-First Century: Charting Directions in Information Services, 203.

ARANZ. (2021). Initial Results from the ARANZ Community Archives Survey. https://www.aranz.org.nz/assets/PDFs/75254ac0b9/Initial-results-of-the-CommunityArchive-Survey.pdf

Archives New Zealand. (2014). Records Management Standard for New Zealand. https://www.otago.ac.nz/administration/corporaterecords/otago073909.pdf

Archives New Zealand. (2020a). Information and records management standard. https://archives.govt.nz/manage-information/resources-andguides/statutory/information-and-records-management-standard

Archives New Zealand. (2020b). Directory of community archives. https://archives.govt.nz/directory-of-community-archives

Bachman, R., \& Schutt, R. (2021). Fundamentals of research in criminology and criminal justice (Fifth edition). SAGE.

Baskerville, R., \& Servalli, S. (2016). Accounting and charities - an introduction. Accounting History, 21(2-3), 139-143. http://dx.doi.org/10.1177/1032373216648423

Benton, P.C. (2008). Understanding data and information systems for record keeping. Facet Publishing. London.

Britannica. (2021). New Zealand. Encyclopædia Britannica. https://www.britannica.com/place/New-Zealand

Brunskill, C. Demb, S. (2012). Records management for museums and galleries: An introduction. Elsevier.

Buckland, M. (1994). On the nature of records management theory. The American Archivist, 346-351. 
Cambridge Dictionary. (2020). Record Keeping: meaning in the Cambridge English Dictionary. https://dictionary.cambridge.org/dictionary/english/record-keeping

Caswell, M., Cifor, M., \& Ramirez, M. H. (2016). "To suddenly discover yourself existing": uncovering the impact of community archives. The American Archivist, 79(1), 56-81

Charities Services. (2021a). About the Charities Register https://www.charities.govt.nz/charities-in-new-zealand/the-charities-register/about-thecharities-register/

Charities Services. (2021b). About the reporting standards. https://www.charities.govt.nz/reporting-standards/about/

Charities Services. (2021c). Which Tier will I use? https://charities.govt.nz/reportingstandards/which-tier-will-i-use/

Charity Commission. (n.d.). Access to Charity Commission records.

https://assets.publishing.service.gov.uk/government/uploads/system/uploads/attachme nt_data/file/356067/accessing-our-records.pdf

Chorley, K. M. (2017). The challenges presented to records management by open government data in the public sector in England. Records Management Journal.

Clubs New Zealand. (2020). What We Do. https://www.clubsnz.org.nz/about/what-we-do/

CommunityNet Aotearoa. (2014). Qualities of an effective charity. https://community.net.nz/resources/charities-services/qualities-of-an-effective-charity/

Copeland, A., Lipinski, T., \& Jones, K. (2017). Collecting, organising, and preserving diverse publication sources for the good of one community archive: Legal challenges and recommendations.

Corporations Canada. (2013). Corporate records and filing obligations - Corporations Canada. http://corporationscanada.ic.gc.ca/eic/site/cd-dgc.nsf/eng/cs05007.html

Crawford, S. (2018). The influence of board leadership and governance on club capacity with the New Zealand community sports clubs. [Masters Dissertation]. Auckland University of Technology.

Department of Internal Affairs [DIA]. (2020). Charities Services / Benefits and obligations/Ngā hua me ngā here. https://www.charities.govt.nz/ready-to- 
register/benefits-and-obligations-of-registered-charities/benefits-and-obligations-ofbeing-registered/

Duis, E. (2014). The involvement of records managers in cloud computing decisions: $A$ cross-sectional study of New Zealand records managers.

Edney, C. M. (2009) Grassroots of Recordkeeping: An investigation into archival practices within rugby clubs of New Zealand. [Masters Dissertation]. Victoria University.

Explora - Australia/New Zealand, (2013). Records management -- principles and practice. http://web.a.ebscohost.com/ehan/pdfviewer/pdfviewer?vid=8\&sid=1798477e-a2b44720-8046-0998f3909019\%40sessionmgr4006

Flinn, A. (2007). Community histories, community archives: Some opportunities and challenges. Journal of the Society of Archivists, 28(2), 151-176.

Flinn, A., Stevens, M., \& Shepherd, E. (2009). Whose memories, whose archives? Independent community archives, autonomy and the mainstream. Archival science, 9(1-2), 71.

Frost, R., \& Untermeyer, L. (1991). The road not taken: a selection of Robert Frost's poems. New York: H. Holt and Company.

Gilliland, A., \& Flinn, A. (2013, October). Community archives: What are we really talking about. In Retrieved from CIRN Prato Community Informatics Conference.

Gradwell, M. (2015). Retention of email records in New Zealand tertiary institutions.

Grant Thornton New Zealand Ltd. (2016) The Challenge of Change: Not for profit sector survey 2015/2016.

https://ndhadeliver.natlib.govt.nz/delivery/DeliveryManagerServlet?dps pid=IE267700 19.

Hill, S. (2016). Governance of small sports clubs in New Zealand: existing structures, processes and potential models [Doctoral dissertation] Lincoln University.

International Council of Archives. (2020). What are archives? https://www.ica.org/en/whatarchive

International Standards Organsiation. (2012). ISO 15489-1:2016(en) Information and Documentation. https://www.iso.org/obp/ui/\#iso:std:iso:15489:-1:en 
Jennex, M. E. Smolnik, S. (2011). Strategies for Knowledge Management Success:

Exploring Organisational Efficacy. Information Science. New York.

Ketelaar, E. (2005). Record-keeping and societal power. Archives: record-keeping in society, 277-98.

Klett, E. (2019). Theory, regulation and practice in Swedish digital records appraisal. Records Management Journal. https://www-emeraldcom.helicon.vuw.ac.nz/insight/content/doi/10.1108/RMJ-09-2018-0027/full/html

Lavrakas, P. J. (2008). Encyclopedia of survey research methods (Vols. 1-0). Thousand Oaks, CA: Sage Publications, Inc. doi: 10.4135/9781412963947

Leedy, P., \& Ormrod, J. (2016). Practical research : planning and design (Eleventh edition). Pearson.

Lewis-Beck, M. S., Bryman, A., \& Futing Liao, T. (2004). The SAGE encyclopedia of social science research methods (Vols. 1-0). Thousand Oaks, CA: Sage Publications, Inc. doi: $10.4135 / 9781412950589$

Library and Archives Canada. (2021). Government Information Management and Disposition - Library and Archives Canada. https://www.bac-lac.gc.ca/eng/services/governmentinformation-resources/Pages/government.aspx

McKemmish, S. (2001). Placing records continuum theory and practice. Archival science, 1(4), 333-359.

Mead Metals Incorporated. (2020). What Exactly is ISO Certified? And Why Does it Matter? https://www.meadmetals.com/blog/what-exactly-is-iso-certified-and-whatdoes-it-mean

Ministry of Education. (n.d.). School Records Retention/Disposal Information Pack https://www.education.govt.nz/assets/Documents/School/Running-a-school/2016SchoolRecordsRetentionDisposalv2.pdf

National Archives Australia [NAA]. (2021a). Developing a records authority. https://www.naa.gov.au/information-management/records-authorities/developingrecords-authority 
National Archives Australia [NAA]. (2021b). Community Heritage Grants. https://www.naa.gov.au/help-your-research/research-grants-andscholarships/community-heritage-grants

National Archives Australia [NAA]. (2021c). Information Management Standard for Australian Government. https://www.naa.gov.au/information-management/informationmanagement-standards/information-management-standard-australian-government

National Archives Australia [NAA]. (2021d). Building trust in the public record: managing information and data government and community. https://www.naa.gov.au/informationmanagement/information-management-policies/building-trust-public-recordpolicy/building-trust-public-record-managing-information-and-data-government-andcommunity

National Library. (2016). Donations. https://natlib.govt.nz/collections/donations

Ndenje-Sichalwe, E., Ngulube, P., \& Stilwell, C. (2011). Managing records as a strategic resource in the government ministries of Tanzania. Information Development, 27(4), 264-279.

New Zealand Companies Office. (2019). Incorporated Societies. https://isregister.companiesoffice.govt.nz/help-centre/getting-started/aboutincorporatedsocieties/

New Zealand Companies Register. (2014). Search Results 'New Zealand' https://app.businessregisters.govt.nz/sbermaster/viewlnstance/view.html?id=36563aba031 f0d65fb0109dc4df52e7d6b3917767e 62ec05\&_timestamp $=4022515663033972$

Not for Profit Resource. (2020). List of non-profits and charities in New Zealand https://www.not-for-profit.org.nz/list-of-non-profits-and-charities-in-new-zealand/

Not-for-Profit NZ (2013). Changes to Legislation - Not for Profit Resource. https://www.notfor-profit.org.nz/legislation/

NZ Navigator Trust. (2021a). Introduction to record keeping. https://community.net.nz/resources/community-resource-kit/introduction-to-recordkeeping/ 
NZ Navigator Trust. (2021b). About community net Aotearoa. https://community.net.nz/about-communitynet-aotearoa/

NZ Navigator Trust. (2021c). About contributing. https://community.net.nz/aboutcommunitynet-aotearoa/about-contributing/

NZ Navigator Trust. (2021d). https://nzntrust.org.nz/

O'Brien, M., Sanders, J., \& Tennant, M. (2009). The New Zealand non-profit sector and government policy. Wellington: Office for the Community and Voluntary Sector.

O'Leary, Z. (2017). The essential guide to doing your research project. Sage.

Oliver, G. Foscarini, F. (2014). Records Management and Information Culture: Tackling the People Problem. ProQuest Ebook Central, http://ebookcentral.proquest.com/lib/vuw/detail.act

Oliver, G., \& Foscarini, F. (2020). Record-keeping cultures (Second edition). Facet.

Parker, E. (2000). Study of the records life cycle. New Review of Academic Librarianship. 6(1), 73-123, DOI: $10.1080 / 13614530009516803$

Perpetual Guardian. (2019). What Is A Trust? https://www.perpetualguardian.co.nz/estateplanning-services/trusts/what-is-a-trust/

Piggott, M. (2012). Archives and societal provenance: Australian essays. Elsevier.

Quintas, P., Lefrere, P., \& Jones, G. (1997). Knowledge management: a strategic agenda. Long range planning, 30(3), 385-391.

Schwartz, J.M. Cook, T. (2002). Archives, records and power: the making of modern memory. Archival Science 2:1-19

Shepherd, E. Yeo, G. (2013). Managing Records: a handbook of principles and practice. In Managing Records. Facet. https://doi.org/10.29085/9781856049788

Shepherd, E., Stevenson, A., \& Flinn, A. (2010). Information governance, records management, and freedom of information: A study of local government authorities in England. Government Information Quarterly, 27(4), 337-345.

Sletten, L. (1999). Lessons from down under: Records management in Australia. Information Management Journal, 33(1), 26-26. 
Spend My Super. (2021). Inspirational Charities in NZ Making a Difference. https://sharemysuper.org.nz/charities

Sport New Zealand (2021a). Find a sport or recreation activity. https://sportnz.org.nz/find-asport-or-recreation-activity/

Sport New Zealand. (2021b). Legal considerations for clubs. https://sportnz.org.nz/resources/legal-considerations-for-clubs/

Statistics New Zealand, (2018). Non-profit institutions satellite account: 2018. https://www.stats.govt.nz/reports/non-profit-institutions-satellite-account-2018

Stevens, M., Flinn, A., \& Shepherd, E. (2010). New frameworks for community engagement in the archive sector: from handing over to handing on. International Journal of Heritage Studies, 16(1-2), 59-76.

Te Papa Tongarewa (2016). Our collections policy. Museum of New Zealand Te Papa Tongarewa, Wellington, NZ. https://www.tepapa.govt.nz/about/collections/ourcollections-policy

The National Archives. (2019). Management Framework for Retention and Transfer Charity Records and Archives.

https://www.nationalarchives.gov.uk/documents/archives/management-framework-forretention-and-transfer.pdf

Thomas, G. (2017). How to do your research project: A guide for students. Sage.

United Nations. (2021). Understanding Records Management / Archives and Records Management Section. https://archives.un.org/content/understanding-recordsmanagement

Upward, F. (2000). Modelling the continuum as paradigm shift in record-keeping and archiving processes, and beyond Ö a personal reflection. Records Management Journal, 10(3), 115-139.

Urban List. (2018). Charities to Get Behind. https://www.theurbanlist.com/nz/a-list/awesomeauckland-charities-to-get-behind

Velasquez, M. (2008). Normative theory versus positive theory. Encyclopedia of business ethics and society, 1524-1525. 
Victoria University of Wellington. (2021). Qualtrics survey tool.

https://www.wgtn.ac.nz/digital-solutions/staff-services/research-services/qualtricssurvey-tool

Wikipedia. (2016).Category: Charities based in New Zealand. Wikimedia Foundation. https://en.wikipedia.org/wiki/Category:Charities_based_in_New_Zealand

Williams, C. (2006). Managing archives: foundations, principles and practice. Elsevier.

Wong, A. (2007). Business archives: using international best practice to evaluate business archives in New Zealand. Research paper. Victoria University of Wellington, 2007.

Xiaomi, A. (2001). A Chinese view of records continuum methodology and implications for managing electronic records.

Yeo, G. (2018). Records, information and data : exploring the role of record-keeping in an information culture. Facet Publishing.

Young, P. (2017). Community Archives \& Heritage Group. Archives and Records Association: UK and Ireland. https://www.archives.org.uk/about/sections-interestgroups/community-archives-aamp-heritage-group-cahg-html

Yusof, Z.M. Chell, R.W. (2000). The Records Life Cycle: an inadequate concept for technology-generated records. Information Development, 16(3), 135-141. https://doi.org/10.1177/0266666004240413 


\begin{tabular}{l|l}
\hline TO & Reesha Ranchod \\
\hline FROM & $\begin{array}{l}\text { Associate Professor Judith Loveridge, Convenor, Human Ethics } \\
\text { Committee }\end{array}$ \\
\hline
\end{tabular}

\begin{tabular}{l|l}
\hline DATE & 16 April 2021 \\
\hline PAGES & 1 \\
\hline
\end{tabular}

\begin{tabular}{l|l}
\hline SUBJECT & $\begin{array}{l}\text { Ethics Approval } \\
\text { Number: 29244 } \\
\text { Title: Record keeping practices in New Zealand non-profit } \\
\text { organisations }\end{array}$ \\
\hline
\end{tabular}

Thank you for your application for ethical approval, which has now been considered by the Human Ethics Committee.

Your application has been approved from the above date and this approval is valid for three years. If your data collection is not completed by this date you should apply to the Human Ethics Committee for an extension to this approval.

Best wishes with the research.

Kind regards,

\section{A. Loweridge}

Judith Loveridge

Convenor, Victoria University of Wellington Human Ethics Committee 


\section{Appendix 2. Information Sheet}

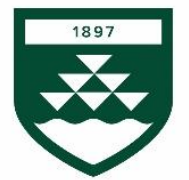

\section{Record-keeping Practices in New Zealand not-for-profit Organisations.}

\section{INFORMATION FOR PARTICIPANTS}

You are invited to take part in this online survey, as part of my research. Please read this information before deciding to take part. If you decide to participate, you have my sincere gratitude. If you decide not to participate, thank you for considering this request.

\section{Who am I?}

My name is Reesha Ranchod, and I am a master's student in Information Studies at Victoria University of Wellington. This research project is the thesis structure required to obtain this degree.

\section{What is the aim of the project?}

This project aims to show what is current practice in records management, specifically record keeping. Secondly, it will assess the need for a general record-keeping schedule (what is required to be kept for accounting purposes and other legislative requirements such as the privacy act) for New Zealand not-for-profit organisations. By providing us information of current processes and what your needs are, your participation will support this research by gaining attention of records managers, and then developing a record keeping schedule. This research has been approved by the Victoria University of Wellington Human Ethics Committee \#29244.

\section{How can you help?}

You have been invited to participate as record keeping processes affect your role as a New Zealand not-for-profit Organisation. Your role may include either managing or volunteering for your non-profit organisation. If you agree to take part, you will complete a survey. The survey will ask you questions about the current record keeping process, and any thoughts about current record keeping standards issued by Archives New Zealand. The survey will take you 10 minutes to complete.

\section{What will happen to the information you give?}

This research is anonymous. This means that nobody, including the researchers will be aware of your identity. By answering it, you are giving consent for us to use your responses in this research. Your answers will remain completely anonymous and unidentifiable. Once you submit the survey, it will be impossible to retract your answer. Please do not include any personal identifiable information in your responses.

\section{What will the project produce?}

The information from your responses will be used in my Master's thesis report.

\section{If you have any questions or problems, who can you contact?}

If you have any questions about the research or ethical conduct, either now or in the future, please feel free to contact either: 
Student:

Reesha Ranchod

ranchorees@myvuw.ac.nz
Supervisor:

Maja Krtalic

Learning and Teaching

Director

School of Information

Management

Phone: 044636915

Maja.krtalic@vuw.ac.nz
Convenor:

Judith Loveridge

Associate Professor

Human Ethics Committee

Phone: 044636028

hec@vuw.ac.nz 


\section{Appendix 3. Survey Questions}

\section{Q1 - Consent}

Yes, I consent to taking this survey

No, I do not consent to taking this survey.

Q2 - Are you involved in the governance, management or administration of this organisation?

Yes

No

Q3 - Records Management: The supervision and administration of digital or paper records. Examples of records are contracts, memos, paper files, electronic files, reports, emails, videos, instant message logs or database records.

Choose one for each statement:

\begin{tabular}{|c|l|l|l|l|l|}
\hline Statements & $\begin{array}{c}\text { Strongly } \\
\text { agree }\end{array}$ & $\begin{array}{c}\text { Somewhat } \\
\text { agree }\end{array}$ & $\begin{array}{l}\text { Neither } \\
\text { agree nor } \\
\text { disagree }\end{array}$ & $\begin{array}{c}\text { Somewhat } \\
\text { disagree }\end{array}$ & $\begin{array}{c}\text { Strongly } \\
\text { disagree }\end{array}$ \\
\hline $\begin{array}{c}\text { Records management is } \\
\text { everyone's responsibility. }\end{array}$ & & & & \\
\hline $\begin{array}{c}\text { Records management } \\
\text { requirements are a barrier } \\
\text { to working efficiently. }\end{array}$ & & & & \\
\hline $\begin{array}{c}\text { Records management is an } \\
\text { essential part of my work. }\end{array}$ & & & & \\
\hline $\begin{array}{c}\text { All staff and volunteers in } \\
\text { my organisation follow a } \\
\text { records management } \\
\text { policy. }\end{array}$ & & & & \\
\hline $\begin{array}{c}\text { I trust our current records } \\
\text { management system. }\end{array}$ & & & & \\
\hline $\begin{array}{c}\text { I have formal training in } \\
\text { records management. }\end{array}$ & & & & \\
\hline $\begin{array}{c}\text { I rely on someone else's } \\
\text { knowledge in records } \\
\text { management. }\end{array}$ & & & & \\
\hline $\begin{array}{c}\text { I trust our current records } \\
\text { policy. }\end{array}$ & & & & \\
\hline
\end{tabular}


Q4 - As you do not have complete faith in a records policy created in your organisation, what are the difficulties that you find with it?
I don't know what our records policy is
I don't understand our record policy
Our records policy is waste of time
I am not willing to invest money into our records management policy
I am not willing to invest time in our records policy
I would like an outside organisation to come in and create a records policy
Other:

\section{Q5 - Current Practice}

Move each of the statements into either that is current practice for you, and the statements you reject, place into not current practise.

\begin{tabular}{|l|l|l|}
\hline \multicolumn{1}{|c|}{ Statements } & $\begin{array}{c}\text { Current } \\
\text { Practice }\end{array}$ & \multicolumn{1}{c|}{$\begin{array}{c}\text { Not Current } \\
\text { Practice }\end{array}$} \\
\hline I always file my emails when they are received. & & \\
\hline I read emails, and then ignore them. & & \\
\hline I delete emails when they are no longer needed. & & \\
\hline I keep bank statements indefinitely. & & \\
\hline I digitise a large number of documentation. & & \\
\hline I prefer to print out all my documentation. & & \\
\hline I archive printed material in appropriate folders. & & \\
\hline I place all documentation in a box, then ignore it. & & \\
\hline I always look for ways to improve my record process. & & \\
\hline
\end{tabular}


Q6 - The following legislation relates to records management. For the following legislation, choose one for each statement.

\begin{tabular}{|c|c|c|c|c|}
\hline Legislation & $\begin{array}{c}\text { I know / have } \\
\text { an awareness } \\
\text { of this } \\
\text { legislation }\end{array}$ & $\begin{array}{c}\text { I understand } \\
\text { this legislation }\end{array}$ & $\begin{array}{c}\text { I apply this } \\
\text { legislation to } \\
\text { our records } \\
\text { management } \\
\text { procedures. }\end{array}$ & $\begin{array}{c}\text { This legislation } \\
\text { is not relevant } \\
\text { for my } \\
\text { organisation }\end{array}$ \\
\hline $\begin{array}{c}\text { Charities Act } \\
2005\end{array}$ & & & \\
\hline $\begin{array}{c}\text { Incorporated } \\
\text { Societies Act } \\
1908\end{array}$ & & & & \\
\hline $\begin{array}{c}\text { Trusts Act 2019 } \\
\text { Copyright Act } \\
1994\end{array}$ & & & & \\
\hline $\begin{array}{c}\text { Income Tax Act } \\
2007\end{array}$ & & & & \\
\hline $\begin{array}{c}\text { Privacy Act } \\
1993\end{array}$ & & & & \\
\hline $\begin{array}{c}\text { Public Records } \\
\text { Act 2005 }\end{array}$ & & & & \\
\hline $\begin{array}{c}\text { Official } \\
\text { Information Act } \\
1982\end{array}$ & & & & \\
\hline
\end{tabular}




\section{Q7 - Archives New Zealand Standards:}

Principle 1: Organisations are responsible for managing information and records

To ensure information and records are able to support all business functions and operations, organisations

must establish a governance framework. This framework will help an organisation to:

- develop strategies and policies to direct how information and records will be managed

- assign responsibilities and allocate resources

- establish provisions for information and records management in outsourcing and service delivery arrangements

- monitor information and records management activities, systems and processes.

\begin{tabular}{|l|l|l|}
\hline Minimum compliance requirements & $\begin{array}{l}\text { Examples of how an organisation can } \\
\text { demonstrate compllance with the requirement }\end{array}$ \\
\hline $\begin{array}{l}\text { Information and records management must } \\
\text { be directed by strategy and policy, and } \\
\text { reviewed and monitored regularly. }\end{array}$ & $\begin{array}{l}\text { Ensure senior executives adopt an } \\
\text { organisation-wide strategy on information and } \\
\text { records management. } \\
\text { Ensure senior executives adopt an } \\
\text { organisation-wide policy on information and } \\
\text { records management. } \\
\text { Monitor how people in the organisation are } \\
\text { applying strategies and policies. }\end{array}$ \\
\hline
\end{tabular}

Archives New Zealand. (2016). Information and records management standard. Retrieved from: https://archives.govt.nz/manage-information/resources-and-guides/statutory/information-andrecords-management-standard

\section{Using the above current record-keeping standard from Archives New Zealand, choose the statements that apply to your organisation:}

The language is simple to understand.

The minimum compliance requirements are achievable.

We currently are following the following principle.

We would require a records manager to understand these principles.

We would need further training to understand these principles.

We would need more funding to have a specialised person to follow these principles. . 


\section{Q8 - Evaluate Current Standards:}

\section{Principle 2: Information and records management supports business}

Information and records management ensures the creation, usability, maintenance, and sustainability of the information and records needed for business operations. It also ensures business operations meet government and community expectations.

By appraising business activities, organisations define their key information requirements. Appraisal is used to design and embed information and records management into business processes and systems.

Taking a planned approach to information and records management means:

- considering all operating environments

- ensuring that all service and systems arrangements consider the creation and management of information and records needed to support business.

\begin{tabular}{|l|l|}
\hline Minimum compliance requirements & $\begin{array}{l}\text { Examples of how an organisation can } \\
\text { demonstrate compliance with the requirement }\end{array}$ \\
\hline $2.1 \quad \begin{array}{l}\text { Information and records required to } \\
\text { support and meet business needs must be } \\
\text { identified. }\end{array}$ & $\begin{array}{l}\text { Document policies, business rules and } \\
\text { procedures on what information and records } \\
\text { are required to meet and support business } \\
\text { needs. } \\
\text { Current, comprehensive appraisal is } \\
\text { documented. } \\
\text { Decisions are documented or reflected in } \\
\text { specifications for systems and metadata } \\
\text { schemas. }\end{array}$ \\
\hline
\end{tabular}

Archives New Zealand. (2016). Information and records management standard. Retrieved from: https://archives.govt.nz/manage-information/resources-and-guides/statutory/information-andrecords-management-standard

\section{Using the above standard from Archives New Zealand, evaluate this with the questions below:}

What concerns do you have about these current standards?

Do you think there should be a general record-keeping schedule for New Zealand nonprofit organisations? 
Q9 - What type of activities / sector does your organisation work within?

Accommodation / Housing

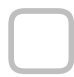

Religious Activities

Education/ Training / Research

Arts / Culture /Heritage

Health / People with disabilities

Sport / Recreation

Community / Social Services

Other

Q10 - What is the balance of paid and volunteer people in your organisation?

Assign a number in these categories; and the total number needs to reach 100.

Full time (35 - 40 hours per week) paid employees:

Part time (less than 44 hours) paid employees:

Any time (any number of hours) volunteers:

Total:

Q11 - What is the total (employees and volunteers) size of your organisation?

Less than 10 people

$11-50$ people

$51-100$ people

More than 100 people 
Q12 - What province of New Zealand is your organisation located?

Northland /Te Tai Tokerau

Auckland / Tāmaki-makau-rau

Waikato

Bay of Plenty / Te Moana-a-Toi

Gisbourne / Te Tai Rāwhiti

Hawke's Bay / Te Matau-a-Māui

Taranaki

Manawatu-Whanganui

Wellington / Te Whanga-nui-a-Tara

Tasman / Te Tai-o-Aorere

Nelson / Whakatū

Marlborough / Te Tauihu-o-te-waka

West Coast /Te Tai Poutini

Canterbury / Waitaha

Otago / Ōtākou

Southland / Murihiku 
Q13 - How long has your non- profit organisation existed?

$0-4$ years $(1)$

5- 9 years (2)

$10-14$ years $(3)$

$15-20$ years $(4)$

$21+$ years $(5)$

Q14 - How long have you been involved with your non-profit organisation?

$0-4$ years $(1)$

5 - 9 years (2)

$10-14$ years $(3)$

$15-20$ years $(4)$

$21+$ years $(5)$

\section{Q15 - Closing Statement:}

Thank you for participating in this survey; please share this survey with others that may benefit from this research. If you have any questions, comments, or concerns email: ranchorees@myvuw.ac.nz

[Summary of Answers given to Participant] 


\section{Appendix 4: Statistical Results}

Q3 - Records Management: The supervision and administration of digital or paper records. Examples of records are contracts, memos, paper files, electronic files, reports, emails, videos, instant message logs or database records. Choose one for each statement:

\begin{tabular}{|c|c|c|c|c|c|c|c|c|c|c|c|c|}
\hline \multirow[b]{2}{*}{ Statements } & \multicolumn{6}{|c|}{$\begin{array}{r}\text { Completed Respondents Count } \\
\text { (Percentage) }\end{array}$} & \multicolumn{6}{|c|}{$\begin{array}{r}\text { Incomplete respondents Count } \\
\text { (Percentage) }\end{array}$} \\
\hline & 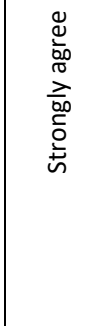 & 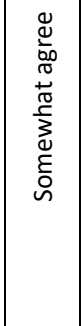 & 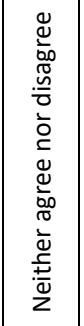 & 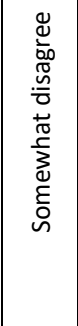 & 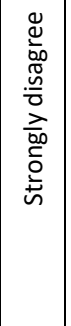 & 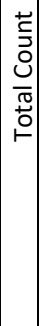 & 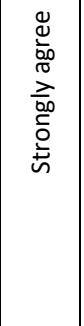 & 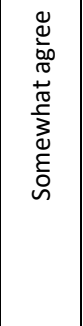 & 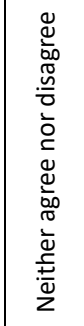 & 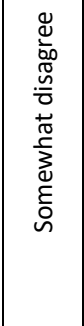 & 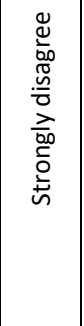 & \\
\hline Records management is everyone's responsibility. & $\begin{array}{r}21 \\
(52.5 \%)\end{array}$ & $\begin{array}{r}14 \\
(35 \%)\end{array}$ & $\begin{array}{r}2 \\
(5 \%)\end{array}$ & $\begin{array}{r}3 \\
(7.5 \% \\
)\end{array}$ & $\begin{array}{r}0 \\
(0 \%)\end{array}$ & $\begin{array}{l}4 \\
0\end{array}$ & $\begin{array}{r}7 \\
(70 \%)\end{array}$ & $\begin{array}{r}3 \\
(30 \%)\end{array}$ & $\begin{array}{r}0 \\
(0 \%)\end{array}$ & $\begin{array}{r}0 \\
(0 \%)\end{array}$ & $\begin{array}{r}0 \\
(0 \%)\end{array}$ & $\begin{array}{l}1 \\
0\end{array}$ \\
\hline $\begin{array}{r}\text { Records management requirements are a barrier to working } \\
\text { efficiently. }\end{array}$ & $\begin{array}{r}2 \\
(5 \%)\end{array}$ & $\begin{array}{r}8 \\
(20 \%)\end{array}$ & $\begin{array}{r}6 \\
(15 \%)\end{array}$ & $\begin{array}{r}14 \\
(35 \%)\end{array}$ & $\begin{array}{r}10 \\
(25 \\
\%) \\
\end{array}$ & $\begin{array}{l}4 \\
0\end{array}$ & $\begin{array}{r}3 \\
(30 \%)\end{array}$ & $\begin{array}{r}1 \\
(10 \%)\end{array}$ & $\begin{array}{r}2 \\
(20 \%)\end{array}$ & $\begin{array}{r}2 \\
(20 \%)\end{array}$ & $\begin{array}{r}2 \\
(20 \%)\end{array}$ & 0 \\
\hline Records management is an essential part of my work. & $\begin{array}{r}25 \\
(62.5 \%)\end{array}$ & $\begin{array}{r}10 \\
(25 \%)\end{array}$ & $\begin{array}{r}2 \\
(5 \%)\end{array}$ & $\begin{array}{r}3 \\
(7.5 \% \\
1\end{array}$ & $\begin{array}{r}0 \\
(0 \%)\end{array}$ & $\begin{array}{l}4 \\
0\end{array}$ & $\begin{array}{r}8 \\
(80 \%)\end{array}$ & $\begin{array}{r}2 \\
(20 \%)\end{array}$ & $\begin{array}{r}0 \\
(0 \%)\end{array}$ & $\begin{array}{r}0 \\
(0 \%)\end{array}$ & $\begin{array}{r}0 \\
(0 \%)\end{array}$ & $\begin{array}{l}1 \\
0\end{array}$ \\
\hline $\begin{array}{r}\text { All staff and volunteers in my organisation follow a records } \\
\text { management policy. }\end{array}$ & $\begin{array}{r}10 \\
(25 \%)\end{array}$ & $\begin{array}{r}10 \\
(25 \%)\end{array}$ & $\begin{array}{r}10 \\
(25 \%)\end{array}$ & $\begin{array}{r}9 \\
(22.5 \\
\%) \\
\end{array}$ & $\begin{array}{r}1 \\
(2.5 \\
\%) \\
\end{array}$ & $\begin{array}{l}4 \\
0\end{array}$ & $\begin{array}{r}3 \\
(30 \%)\end{array}$ & $\begin{array}{r}3 \\
(30 \%)\end{array}$ & $\begin{array}{r}2 \\
(20 \%)\end{array}$ & $\begin{array}{r}2 \\
(20 \%)\end{array}$ & $\begin{array}{r}0 \\
(0 \%)\end{array}$ & $\begin{array}{l}1 \\
0\end{array}$ \\
\hline I trust our current records management system. & $\begin{array}{r}15 \\
(37.5 \%)\end{array}$ & $\begin{array}{r}11 \\
(27.5 \\
\%) \\
\end{array}$ & \begin{tabular}{|r|}
5 \\
$(12.5$ \\
$\%)$ \\
\end{tabular} & $\begin{array}{r}6 \\
(15 \%) \\
\end{array}$ & $\begin{array}{r}3 \\
(7.5 \\
\%) \\
\end{array}$ & \begin{tabular}{l|l}
4 \\
0
\end{tabular} & $\begin{array}{r}3 \\
(30 \%)\end{array}$ & $\begin{array}{r}6 \\
(60 \%)\end{array}$ & $\begin{array}{r}1 \\
(10 \%)\end{array}$ & $\begin{array}{r}0 \\
(0 \%)\end{array}$ & $\begin{array}{r}0 \\
(0 \%)\end{array}$ & \begin{tabular}{|l}
1 \\
0
\end{tabular} \\
\hline I have formal training in records management. & $\begin{array}{r}6 \\
(15 \%)\end{array}$ & $\begin{array}{r}8 \\
(20 \%)\end{array}$ & $\begin{array}{r}5 \\
(12.5 \\
\%) \\
\end{array}$ & $\begin{array}{r}3 \\
(7.5 \% \\
1 \\
\end{array}$ & $\begin{array}{r}18 \\
(45 \\
\%)\end{array}$ & \begin{tabular}{l|}
4 \\
0
\end{tabular} & $\begin{array}{r}2 \\
(20 \%)\end{array}$ & $\begin{array}{r}2 \\
(20 \%)\end{array}$ & $\begin{array}{r}1 \\
(10 \%)\end{array}$ & $\begin{array}{r}0 \\
(0 \%)\end{array}$ & $\begin{array}{r}5 \\
(50 \%)\end{array}$ & $\begin{array}{l}1 \\
0\end{array}$ \\
\hline I rely on someone else's knowledge in records management. & $\begin{array}{r}3 \\
(7.5 \%)\end{array}$ & $\begin{array}{r}4 \\
(10 \%)\end{array}$ & $\begin{array}{r}9 \\
(22.5 \\
\%) \\
\end{array}$ & $\begin{array}{r}12 \\
(30 \%)\end{array}$ & $\begin{array}{r}12 \\
(30 \\
\%) \\
\end{array}$ & \begin{tabular}{l|}
4 \\
0
\end{tabular} & $\begin{array}{r}0 \\
(0 \%)\end{array}$ & $\begin{array}{r}3 \\
(30 \%)\end{array}$ & $\begin{array}{r}3 \\
(30 \%)\end{array}$ & $\begin{array}{r}2 \\
(20 \%)\end{array}$ & $\begin{array}{r}2 \\
(20 \%)\end{array}$ & $\begin{array}{l}1 \\
0\end{array}$ \\
\hline I trust our current records policy. & $\begin{array}{r}13 \\
(32.5 \%)\end{array}$ & \begin{tabular}{|r|}
13 \\
$(32.5$ \\
$\%)$
\end{tabular} & $\begin{array}{r}8 \\
(20 \%)\end{array}$ & $\begin{array}{r}4 \\
(10 \%)\end{array}$ & $\begin{array}{r}2 \\
(5 \%)\end{array}$ & \begin{tabular}{l|}
4 \\
0 \\
\end{tabular} & $\begin{array}{r}4 \\
(40 \%)\end{array}$ & $\begin{array}{r}2 \\
(20 \%)\end{array}$ & $\begin{array}{r}3 \\
(30 \%)\end{array}$ & $\begin{array}{r}0 \\
(0 \%)\end{array}$ & $\begin{array}{r}1 \\
(10 \%)\end{array}$ & $\begin{array}{l}1 \\
0\end{array}$ \\
\hline
\end{tabular}

Table 11: Results of records management statements. 


\begin{tabular}{|c|c|c|c|c|c|c|}
\hline Field & & 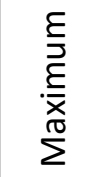 & $\begin{array}{l}\frac{c}{\mathbb{d}} \\
\stackrel{\mathbb{d}}{\Sigma}\end{array}$ & 总 & 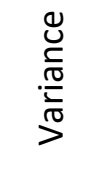 & 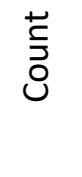 \\
\hline Records management is everyone's responsibility. & 1.00 & 4.00 & 1.68 & 0.88 & 0.77 & 40 \\
\hline $\begin{array}{r}\text { Records management requirements are a barrier to } \\
\text { working efficiently. }\end{array}$ & 1.00 & 5.00 & 3.55 & 1.20 & 1.45 & 0 \\
\hline Records management is an essential part of my work. & 1.00 & 4.00 & 1.57 & 0.89 & 0.79 & 0 \\
\hline $\begin{array}{l}\text { All staff and volunteers in my organisation follow a } \\
\text { records management policy. }\end{array}$ & 1.00 & 5.00 & 2.52 & 1.16 & 1.35 & 0 \\
\hline I trust our current records management system. & 1.00 & 5.00 & 2.27 & 1.30 & 1.70 & 40 \\
\hline I have formal training in records management. & 1.00 & 5.00 & 3.48 & 1.57 & 2.45 & 40 \\
\hline $\begin{array}{r}\text { I rely on someone else's knowledge in records } \\
\text { management. }\end{array}$ & 1.00 & 5.00 & 3.65 & 1.22 & 1.48 & \\
\hline I trust our current records policy. & 1.00 & 5.00 & 2.23 & 1.15 & 1.32 & 4 \\
\hline
\end{tabular}


Q4 As you do not have complete faith in a records policy created in your organisation, what are the difficulties that you find with it?

\begin{tabular}{|c|c|c|c|}
\hline Answer & $\begin{array}{r}\text { Complete Respondents } \\
\text { Count (Percentage) }\end{array}$ & $\begin{array}{r}\text { Incomplete } \\
\text { Respondents } \\
\text { Count } \\
\text { (Percentage) }\end{array}$ & Total \\
\hline I don't know what our records policy is & $5(31.2 \%)$ & 2 (40\%) & 7 \\
\hline I don't understand our record policy & $2(12.5 \%)$ & $0(0 \%)$ & 2 \\
\hline Our records policy is waste of time & $1(6.2 \%)$ & $0(0 \%)$ & 1 \\
\hline $\begin{array}{l}\text { I am not willing to invest money into our } \\
\text { records management policy }\end{array}$ & $0(0 \%)$ & $0(0 \%)$ & 0 \\
\hline $\begin{array}{r}\text { I am not willing to invest time in our } \\
\text { records policy }\end{array}$ & $0(0 \%)$ & $0(0 \%)$ & 0 \\
\hline $\begin{array}{l}\text { I would like an outside organisation to } \\
\text { come in and create a records policy }\end{array}$ & $3(18.8 \%)$ & $1(20 \%)$ & 4 \\
\hline Other & $5(31.2 \%)$ & $2(40 \%)$ & 7 \\
\hline Total & 16 & 5 & 21 \\
\hline
\end{tabular}

\section{Q4 - Other, text responses:}

Other - Non Completed Respondents

- It needs to be updated to a more reliable system

- policy can be improved on but efficient enough

Other - Completed Respondents

- We don't have a written one.

- We are an organisation that has combined 40 plus organisations into one, which has meant that are various levels of record keeping across the organisation

- We have had external support but have not managed to get the culture of responsibility happening with staff

- I do not have time nor enough knowledge to invest in developing a policy

- We don't have a records policy as such 
Q5 - Move each of the statements into either that is "Current Practice" for you, and the statements you reject, place into 'Not Current Practice".

\begin{tabular}{|c|c|c|c|c|c|c|}
\hline \multirow[b]{2}{*}{ Statements } & \multicolumn{2}{|c|}{$\begin{array}{r}\text { Completed Respondents } \\
\text { Count (Percentage) }\end{array}$} & \multicolumn{2}{|c|}{$\begin{array}{r}\text { Incomplete Respondents } \\
\text { Count (Percentage) }\end{array}$} & \multicolumn{2}{|c|}{ Total } \\
\hline & 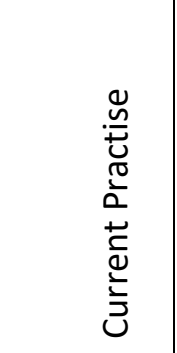 & 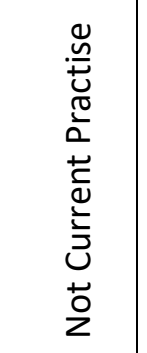 & 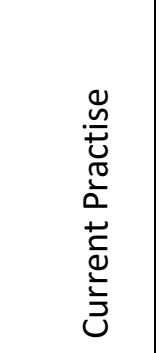 & 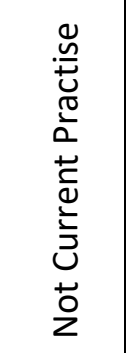 & 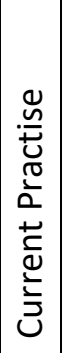 & 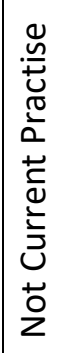 \\
\hline $\begin{array}{r}\text { I always file my emails when they } \\
\text { are received. }\end{array}$ & $\begin{array}{r}23 \\
(57.5 \%)\end{array}$ & $\begin{array}{r}17 \\
42.5 \%\end{array}$ & $\begin{array}{r}9 \\
(90 \%)\end{array}$ & $\begin{array}{r}1 \\
(10 \%)\end{array}$ & 40 & 10 \\
\hline $\begin{array}{r}\text { I read emails, and then ignore } \\
\text { them. }\end{array}$ & $\begin{array}{r}4 \\
(10.3 \%)\end{array}$ & $\begin{array}{r}35 \\
89.7 \%\end{array}$ & $\begin{array}{r}1 \\
(10 \%)\end{array}$ & $\begin{array}{r}9 \\
(90 \%)\end{array}$ & 39 & 10 \\
\hline $\begin{array}{r}\text { I delete emails when they are no } \\
\text { longer needed. }\end{array}$ & $\begin{array}{r}22 \\
(56.4 \%) \\
\end{array}$ & $\begin{array}{r}17 \\
18.5 \% \\
\end{array}$ & $\begin{array}{r}5 \\
(50 \%)\end{array}$ & $\begin{array}{r}5 \\
(50 \%) \\
\end{array}$ & 39 & 10 \\
\hline $\begin{array}{r}\text { I keep bank statements } \\
\text { indefinitely. }\end{array}$ & $\begin{array}{r}20 \\
(50 \%) \\
\end{array}$ & $\begin{array}{r}20 \\
(50 \%)\end{array}$ & $\begin{array}{r}4 \\
(40 \%)\end{array}$ & $\begin{array}{r}6 \\
(60 \%)\end{array}$ & 40 & 10 \\
\hline $\begin{array}{r}\text { I digitize a large number of } \\
\text { documentation. }\end{array}$ & $\begin{array}{r}31 \\
(77.5 \%) \\
\end{array}$ & $\begin{array}{r}9 \\
(22.5 \%) \\
\end{array}$ & $\begin{array}{r}7 \\
(70 \%)\end{array}$ & $\begin{array}{r}3 \\
(30 \%) \\
\end{array}$ & 40 & 10 \\
\hline $\begin{array}{r}\text { I prefer to print out all of my } \\
\text { documentation. }\end{array}$ & $\begin{array}{r}6 \\
(15.8 \%)\end{array}$ & $\begin{array}{r}32 \\
(84.8 \%)\end{array}$ & $\begin{array}{r}2 \\
(20 \%)\end{array}$ & $\begin{array}{r}8 \\
(80 \%)\end{array}$ & 38 & 10 \\
\hline $\begin{array}{r}\text { I archive printed material in } \\
\text { appropriate folders. }\end{array}$ & $\begin{array}{r}33 \\
(82.5 \%)\end{array}$ & $\begin{array}{r}7 \\
(17.5 \%) \\
\end{array}$ & $\begin{array}{r}8 \\
(80 \%)\end{array}$ & $\begin{array}{r}2 \\
(20 \%) \\
\end{array}$ & 40 & 10 \\
\hline $\begin{array}{l}\text { I place all documentation in a } \\
\text { box, then ignore it. }\end{array}$ & $\begin{array}{r}3 \\
(7.6 \%)\end{array}$ & $\begin{array}{r}36 \\
(92.3 \%)\end{array}$ & $\begin{array}{r}0 \\
(0 \%)\end{array}$ & $\begin{array}{r}10 \\
(100 \%)\end{array}$ & 39 & 10 \\
\hline $\begin{array}{l}\text { I always look for ways to improve } \\
\text { my record process. }\end{array}$ & $\begin{array}{r}35 \\
(87.5 \%)\end{array}$ & $\begin{array}{r}5 \\
(12.5 \%)\end{array}$ & $\begin{array}{r}9 \\
(90 \%)\end{array}$ & $\begin{array}{r}1 \\
(10 \%)\end{array}$ & 40 & 10 \\
\hline
\end{tabular}

Table 14: Results of Current and Not Current Practise statements. 

legislation, choose one for each statement.

\begin{tabular}{|c|c|c|c|c|c|c|}
\hline & 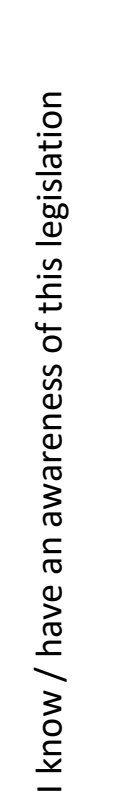 & 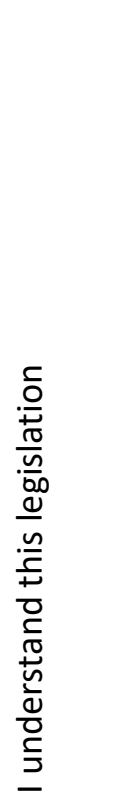 & 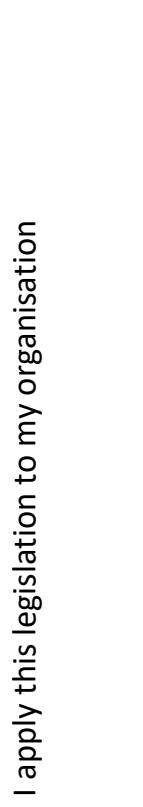 & 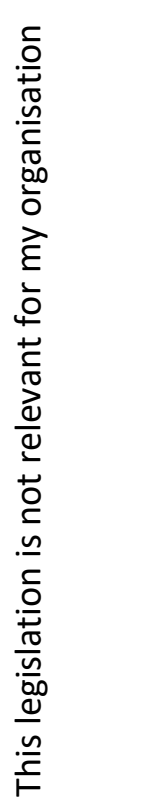 & $\begin{array}{l}\frac{n}{\pi} \\
\stackrel{0}{0} \\
\vdash\end{array}$ & \\
\hline $\begin{array}{r}\text { Charities Act } \\
2005\end{array}$ & $\begin{array}{r}12 \\
(30.7 \%)\end{array}$ & $\begin{array}{r}3 \\
(7.6 \%)\end{array}$ & $\begin{array}{r}19 \\
(48.7 \%)\end{array}$ & $\begin{array}{r}5 \\
(12.8 \%)\end{array}$ & & 39 \\
\hline $\begin{array}{r}\text { Incorporated } \\
\text { Societies Act } \\
1908\end{array}$ & $\begin{array}{r}14 \\
(37.8 \%)\end{array}$ & $\begin{array}{r}3 \\
(8.1 \%)\end{array}$ & $\begin{array}{r}15 \\
(40.5 \%)\end{array}$ & $\begin{array}{r}5 \\
(13.5 \%)\end{array}$ & & 37 \\
\hline $\begin{array}{r}\text { Trusts Act } \\
2019\end{array}$ & $\begin{array}{r}8 \\
(21 \%)\end{array}$ & $\begin{array}{r}2 \\
(5.2 \%)\end{array}$ & $\begin{array}{r}10 \\
(26.3 \%)\end{array}$ & $\begin{array}{r}18 \\
(47.3 \%)\end{array}$ & & 38 \\
\hline $\begin{array}{r}\text { Copyright Act } \\
1994\end{array}$ & $\begin{array}{r}13 \\
(35.1 \%)\end{array}$ & $\begin{array}{r}4 \\
(10.8 \%)\end{array}$ & $\begin{array}{r}11 \\
(29.7 \%)\end{array}$ & $\begin{array}{r}9 \\
(24.3 \%)\end{array}$ & & 37 \\
\hline $\begin{array}{r}\text { Income Tax } \\
\text { Act } 2007\end{array}$ & $\begin{array}{r}9 \\
(23.6 \%)\end{array}$ & $\begin{array}{r}3 \\
(7.8 \%)\end{array}$ & $\begin{array}{r}15 \\
(39.4 \%)\end{array}$ & $\begin{array}{r}11 \\
(28.9 \%)\end{array}$ & & 38 \\
\hline $\begin{array}{r}\text { Privacy Act } \\
1993\end{array}$ & $\begin{array}{r}13 \\
(35.1 \%)\end{array}$ & $\begin{array}{r}3 \\
(8.1 \%)\end{array}$ & $\begin{array}{r}20 \\
(54 \%)\end{array}$ & $\begin{array}{r}1 \\
(2.7 \%)\end{array}$ & & 37 \\
\hline $\begin{array}{r}\text { Public } \\
\text { Records Act } \\
2005\end{array}$ & $\begin{array}{r}14 \\
(36.8 \%)\end{array}$ & $\begin{array}{r}5 \\
(13.2 \%)\end{array}$ & $\begin{array}{r}8 \\
(21.1 \%)\end{array}$ & $\begin{array}{r}11 \\
(28.9 \%)\end{array}$ & & 38 \\
\hline $\begin{array}{r}\text { Official } \\
\text { Information } \\
\text { Act } 1982\end{array}$ & $\begin{array}{r}15 \\
(39.5 \%)\end{array}$ & $\begin{array}{r}7 \\
(18.4 \%)\end{array}$ & $\begin{array}{r}9 \\
(23.7 \%)\end{array}$ & $\begin{array}{r}7 \\
(18.4 \%)\end{array}$ & & 38 \\
\hline
\end{tabular}


Q7 - Archives New Zealand Standards: Using the above current record-keeping standard from Archives New Zealand, choose the statements that apply to your organisation:

\begin{tabular}{|c|c|c|}
\hline Answer & $\%$ & Count \\
\hline The language is simple to understand. & $29.17 \%$ & 28 \\
\hline The minimum compliance requirements are achievable. & $26.04 \%$ & 25 \\
\hline We currently are following the following principle. & $16.67 \%$ & 16 \\
\hline We would require a records manager to understand these principles. & $3.13 \%$ & 3 \\
\hline We would need further training to understand these principles. & $10.42 \%$ & 10 \\
\hline $\begin{array}{r}\text { We would need more funding to have a specialised person to follow these } \\
\text { principles. }\end{array}$ & $14.58 \%$ & 14 \\
\hline Total & $100 \%$ & 96 \\
\hline
\end{tabular}

Table 16: Results of application of principle 1.

Q8 - Evaluate Standards: Using the above standard from Archives New Zealand, evaluate this with the questions below:

\begin{tabular}{|c|c|c|}
\hline Answer & $\%$ & Count \\
\hline What concerns do you have about these current standards? & $47.30 \%$ & 35 \\
\hline $\begin{array}{r}\text { Do you think there should be a general record-keeping schedule for New } \\
\text { Zealand non-profit organisations? }\end{array}$ & $52.70 \%$ & 39 \\
\hline Total & $100 \%$ & 74 \\
\hline
\end{tabular}

Table 17: Number of Respondents answering Q8a and Q8b. 


\section{Q8a: What concerns do you have about these current standards?}

\section{Time Management:}

- They are not well understood or known, it takes time and effort to develop this

Standards not needed:

Most info and records are filed and kept for specific reasons - audit, project management. Standards are not specific but too much specificity is not always needed

\section{No Staff or Funding:}

- charities have barely enough resources to run in a reactive manner, and investing in documenting fully processes, policies \& business rules is unlikely in even our highest performing charities.

- We don't have the staff or funding to spend time trying to comply with this.

Training Needed:

For a small club the person in the Secretary role is assumed to be on top of this. A significant effort is needed to educate prospective secretaries in these matters

\section{Missing the Mark:}

- Not being achieved by some non profit organisations.

- potentially currently not meeting the requirements

- That our organisation does not have a current records policy in place so is therefore non compliant

- Unsure if we are complying with these standards

- Some NFP organisations may find it difficult to follow these standards. Charities are in 4 different Tiers and have different requirements which should be applied to the Archive NZ standards 'different courses for different horses'. We are Tier 2 so have different requirements to a Tier 4 charity
None (x 11)

- As we have considerably more statutory requirements about our record keeping than what you have mentioned, these are minimum requirements for us and so I have no concerns

\section{Clarification Needed:}

- hard to understand

- Complex and ambiguous in many instances. Open to interpretation

- It is very vague

- What others may deem important records to keep may not be the same ones staff would identify as being of importance

- Not simple enough for volunteers who are sometimes the ones who are running a non profit org / charity

- We run programmes licensed by different government departments and they have different requirements for record keeping which is confusing! We just keep everything for 7 years to be safe!!!

- Nothing about digital and how do we keep them safe?

Other:

- It is somewhat bureaucratic for a very small orgabnisation

- $\quad$ remote working results in files being stored in other locations rather than in our electronic or physical environment

- other than me - no-one here knows what metadata is - and no one uses it.

- too much work

- It is not enough to state the minimum standard, this falls short of sufficient compliance requirements given the nature of the legislation around record keeping.

- To be in the current system and follow the regulation

Table 18: Responses of current standards concerns. 


\section{Q8b: Do you think there should be a general record-keeping schedule for New}

\section{Zealand?}

Do you think there should be a general record-keeping schedule for New Zealand non-profit organisations? - Text

Yes: $x 22$

- As long as it is practical and limited to types of docs that are specifically required.

- Yes. all non profits have income from the public, so accountability is important.

- That sounds like a great option

- That would be fantastic!

- We need consistency across the board.

- NFPs need the heavy work done for them so that compliance is as easy as copy cataloguing.

- and better framework templates that relate to the kaupapa of the org.

- non-profit organisations are no different to commercial businesses. There is a governance requirements to ensure records are handled appropriately

- We have to be transparent on this sensitive issue
No: $\times 9$

- I think a general record-keeping schedule would not capture specifics for the vast range of nonprofit organisations operating. This would be just one more system/process that would need to be kept updated, this requires man power, one of the biggest resource constraints is man power.

- If there were a schedule, the monitoring and checking for compliance wouyld undoubtedly add a cost to our NGO that runs on a koha basis and is underfunded

- We all have different needs to I cannot see what the point is. Most of our records are now electronic and therefore filed according to the information system they are recorded in.

\section{Other Comments:}

- Maybe, having everyone doing the same thing in the same way might be useful

- A very general record keeping schedule might be useful but not as a compliance thing. Laws re employment, accounting records, governance already exist

- It would be handy to know exactly what we're required to keep

- and training

- it would reduce the duplication of effort for many organisations.

- I think that adding more compliance to a charity is going to mean more hours for volunteers and that pressure is too much

- Not sure I understand enough to comment properly, but in principle it sounds good.

- Probably but it needs to be relevant to the charity and what Tier they are in

- i doubrt that many smaller organisations would be capable of following it

- hard to understand

Table 19: Creating standards responses. 
Q9 - What type of activities / sector does your organisation work within?

\begin{tabular}{r|r|r|} 
Answer & $\%$ & Count \\
\hline Accommodation / Housing & $2.82 \%$ & 2 \\
\hline Religious Activities & $7.04 \%$ & 5 \\
\hline Education/ Training / Research & $15.49 \%$ & 11 \\
\hline Arts / Culture /Heritage & $5.63 \%$ & 4 \\
\hline Health / People with disabilities & $15.49 \%$ & 11 \\
\hline Sport / Recreation & $11.27 \%$ & 8 \\
\hline Community / Social Services & $32.39 \%$ & 23 \\
\hline Other & $9.86 \%$ & 7 \\
\hline Total & $100 \%$ & 71 \\
\hline
\end{tabular}

Table 20: Results of organisation sectors

Statistics New Zealand (2018) Current Research

\begin{tabular}{|c|c|c|c|c|}
\hline Non-profit institutions & $\begin{array}{r}2013 \\
\text { Number (\%) }\end{array}$ & $\begin{array}{r}2018 \\
\text { Number (\%) }\end{array}$ & $\begin{array}{r}2021 \\
\text { Number (\%) }\end{array}$ & 2021 Sectors \\
\hline Culture, sport, and recreation & $\begin{array}{r}50,380 \\
(44.2 \%)\end{array}$ & $\begin{array}{r}51,820 \\
(44.8 \%)\end{array}$ & $\begin{array}{r}12 \\
(16.9 \%)\end{array}$ & $\begin{array}{l}\text { Arts/Culture/Heritage, } \\
\text { Sport/Recreation }\end{array}$ \\
\hline Education and research & $\begin{array}{r}7,960 \\
(7.0 \%)\end{array}$ & $\begin{array}{r}8,390 \\
(7.2 \%)\end{array}$ & $\begin{array}{r}11 \\
(15.5 \%)\end{array}$ & Education/Training/ Research \\
\hline Health & $\begin{array}{r}3,010 \\
(2.6 \%)\end{array}$ & $\begin{array}{r}2,920 \\
(2.5 \%)\end{array}$ & $\begin{array}{r}11 \\
(15.5 \%)\end{array}$ & Health/People with Disabilities \\
\hline Social services & $\begin{array}{r}14,810 \\
(13.0 \%)\end{array}$ & $\begin{array}{r}14,130 \\
(12.2 \%)\end{array}$ & $\begin{array}{r}23 \\
(32.4 \%)\end{array}$ & Community/Social Services \\
\hline Environment & $\begin{array}{r}1,850 \\
(1.6 \%)\end{array}$ & $\begin{array}{r}2,060 \\
(1.8 \%)\end{array}$ & $\begin{array}{r}0 \\
(0 \%)\end{array}$ & \\
\hline Development and housing & $\begin{array}{r}9,680 \\
(8.5 \%)\end{array}$ & $\begin{array}{r}8,860 \\
(7.7 \%)\end{array}$ & $\begin{array}{r}2 \\
(2.8 \%)\end{array}$ & Accomodation and Housing \\
\hline Law, advocacy and politics & $\begin{array}{r}3,190 \\
(2.8 \%)\end{array}$ & $\begin{array}{r}3,850 \\
(3.3 \%)\end{array}$ & $\begin{array}{r}0 \\
(0 \%)\end{array}$ & \\
\hline $\begin{array}{l}\text { Grant making, fundraising and } \\
\text { voluntarism promotion }\end{array}$ & $\begin{array}{r}1,210 \\
(1.1 \%)\end{array}$ & $\begin{array}{r}1,580 \\
(1.4 \%)\end{array}$ & $\begin{array}{r}0 \\
(0 \%)\end{array}$ & \\
\hline International & $\begin{array}{r}630 \\
(0.6 \%)\end{array}$ & $\begin{array}{r}880 \\
(0.8 \%)\end{array}$ & $\begin{array}{r}0 \\
(0 \%)\end{array}$ & \\
\hline Religion & $\begin{array}{r}9,440 \\
(8.3 \%)\end{array}$ & $\begin{array}{r}10,130 \\
(8.8 \%)\end{array}$ & $\begin{array}{r}5 \\
(7 \%)\end{array}$ & Religious Activities \\
\hline $\begin{array}{l}\text { Business and professional } \\
\text { associations, unions }\end{array}$ & $\begin{array}{r}3,110 \\
(2.7 \%)\end{array}$ & $\begin{array}{r}3,690 \\
(3.2 \%)\end{array}$ & $\begin{array}{r}0 \\
(0 \%)\end{array}$ & \\
\hline $\begin{array}{l}\text { Not elsewhere classified (residual } \\
\text { category) }\end{array}$ & $\begin{array}{r}8,840 \\
(7.7 \%)\end{array}$ & $\begin{array}{r}7,470 \\
(6.5 \%)\end{array}$ & $\begin{array}{r}7 \\
(9.9 \%)\end{array}$ & Other \\
\hline Total & 114,110 & 115,770 & 71 & Total \\
\hline
\end{tabular}

Table 21: Comparison of non-profit institutions from Statistics New Zealand (2018) 
Q10 - What is the balance of paid and volunteer people in your organisation? Assign a number in these categories; and the total number needs to reach 100 .

\begin{tabular}{|c|c|c|c|c|c|c|}
\hline Field & Minimum & Maximum & Mean & $\begin{array}{r}\text { Std } \\
\text { Deviation }\end{array}$ & Variance & Count \\
\hline $\begin{array}{r}\text { Full time (35 - } 40 \text { hours } \\
\text { per week) paid } \\
\text { employees. }\end{array}$ & 0.00 & 85.00 & 12.72 & 22.80 & 519.65 & 40 \\
\hline $\begin{array}{l}\text { Part time (less than } 44 \\
\text { hours) paid employees. }\end{array}$ & 0.00 & 100.00 & 14.85 & 21.21 & 449.98 & 40 \\
\hline $\begin{array}{l}\text { Any time (any number } \\
\text { of hours) volunteers }\end{array}$ & 0.00 & 14000.00 & 412.65 & 2179.23 & 4749052.73 & 40 \\
\hline
\end{tabular}

\begin{tabular}{l|l|l|l|l}
$\begin{array}{l}\text { Number of } \\
\text { Employees }\end{array}$ & $\begin{array}{l}\text { Number (Statistics } \\
\text { New Zealand, } \\
2018)\end{array}$ & $\begin{array}{l}\text { Percentage } \\
\text { (Statistics New } \\
\text { Zealand, 2018) }\end{array}$ & $\begin{array}{l}\text { Number } \\
\text { (Q10) }\end{array}$ & $\begin{array}{l}\text { Percentage } \\
\text { (Q10) }\end{array}$ \\
\hline 0 & 103,272 & $89.2 \%$ & 4 & $10 \%$ \\
\hline $1-5$ & 8433 & $7.3 \%$ & 12 & $30 \%$ \\
\hline $6-19$ & 2829 & $2.4 \%$ & 8 & $20 \%$ \\
\hline $20-99$ & 1029 & $0.9 \%$ & 14 & $35 \%$ \\
\hline $100+$ & 225 & $0.2 \%$ & 2 & $5 \%$ \\
\hline \multicolumn{2}{r}{ Table 23: Comparison from Statistics New Zealand (2018); makeup of employees and volunteers. }
\end{tabular}

Q11 - What is the total (employees and volunteers) size of your organisation?

\begin{tabular}{r|r|r} 
Answer & $\%$ & Count \\
\hline Less than 10 people & $27.50 \%$ & 11 \\
\hline $11-50$ people & $37.50 \%$ & 15 \\
\hline $51-100$ people & $17.50 \%$ & 7 \\
\hline More than 100 people & $17.50 \%$ & 7 \\
\hline Total & $100 \%$ & 40
\end{tabular}

Table 24: Results of size of organisation. 
Q12 - What province of New Zealand is your organisation located

\begin{tabular}{|c|c|c|}
\hline Answer & $\%$ & Count \\
\hline Northland /Te Tai Tokerau & $2.47 \%$ & 2 \\
\hline Auckland / Tāmaki-makau-rau & $22.22 \%$ & 18 \\
\hline Waikato & $6.17 \%$ & 5 \\
\hline Bay of Plenty / Te Moana-a-Toi & $8.64 \%$ & 7 \\
\hline Gisbourne / Te Tai Rāwhiti & $2.47 \%$ & 2 \\
\hline Hawke's Bay / Te Matau-a-Māui & $4.94 \%$ & 4 \\
\hline Taranaki & $4.94 \%$ & 4 \\
\hline Manawatu-Whanganui & $3.70 \%$ & 3 \\
\hline Wellington / Te Whanga-nui-a-Tara & $17.28 \%$ & 14 \\
\hline Tasman / Te Tai-o-Aorere & $3.70 \%$ & 3 \\
\hline Nelson / Whakatū & $3.70 \%$ & 3 \\
\hline Marlborough / Te Tauihu-o-te-waka & $2.47 \%$ & 2 \\
\hline West Coast /Te Tai Poutini & $2.47 \%$ & 2 \\
\hline Canterbury / Waitaha & $6.17 \%$ & 5 \\
\hline Otago / Ōtākou & $4.94 \%$ & 4 \\
\hline Southland / Murihiku & $3.70 \%$ & 3 \\
\hline Total & $100 \%$ & 81 \\
\hline
\end{tabular}

Table 25: Province location of organisations.

Q13 - How long has your non-profit organisation existed?

\begin{tabular}{r|r|r|} 
Answer & $\%$ & Count \\
\hline $0-4$ years & $7.50 \%$ & 3 \\
\hline $5-9$ years & $7.50 \%$ & 3 \\
\hline $10-14$ years & $20.00 \%$ & 8 \\
\hline $15-20$ years & $7.50 \%$ & 3 \\
\hline $21+$ years & $57.50 \%$ & 23 \\
\hline Total & $100 \%$ & 40 \\
\hline Table 26: Result of length of time for organisations.
\end{tabular}


Q14: - How long have you been involved with your non-profit organisation?

\begin{tabular}{r|r|r|} 
Answer & $\%$ & Count \\
\hline $0-4$ years & $35.00 \%$ & 14 \\
\hline $5-9$ years & $37.50 \%$ & 15 \\
\hline $10-14$ years & $5.00 \%$ & 2 \\
\hline $15-20$ years & $12.50 \%$ & 5 \\
\hline $21+$ years & $10.00 \%$ & 4 \\
\hline Total & $100 \%$ & 40 \\
\hline
\end{tabular}

Table 26: Result of length of involvement with organisations. 